\title{
Combined facility location and distribution network design problem: Progressive models and a case study
}

\author{
Birleşik depo yeri seçimi ve dağıtım ağı tasarımı problemi: \\ Aşamalı modeller ve bir uygulama
}

\author{
Ibrahim KUCUKKOC ${ }^{*}$ iD , Mustafa ACAR ${ }^{2}$ iD \\ ${ }^{1}$ Department of Industrial Engineering, Faculty of Engineering, Balikesir University, Balikesir, Turkey. \\ ikucukkoc@balikesir.edu.tr \\ ${ }^{2}$ National Defence University, Istanbul, Turkey. \\ gokden1307@gmail.com
}

Received/Geliş Tarihi: 21.04.2019, Accepted/Kabul Tarihi: 11.07.2019

doi: $10.5505 /$ pajes.2019.11456

* Corresponding author/Yazışılan Yazar Research Article/Araștırma Makalesi

\begin{abstract}
This paper addresses to the facility location problem of ammunition stores considering the design of distribution network from stores to geographically dispersed army forces. The problem is to determine the construction sites of the ammunition stores among candidate sites and to give the decision on how many stores will be built from which kind. The problem also contains designing of a distribution network to concurrently determine the amounts of several military equipment transported from stores to army forces. A mathematical model is proposed to minimize the cost of the whole system, caused by the construction of the ammunition stores and the transportation of different equipment in diverse quantities from stores to dispersed army forces. The model is then improved progressively and several variants are presented to reflect the real-world conditions through a case study. Numerical results obtained from solving the case study using the proposed models coded in General Algebraic Modelling System (GAMS) are exhibited. The effect of the size of problem specific parameters on the model execution time is also investigated via experimental tests. The results demonstrate the promising problem-solving capacity of the proposed models, which can be applied practically.
\end{abstract}

Keywords: Facility location, Distribution network design, Operations research, MILP

\section{Introduction}

Facility location decisions are usually long-term decisions and fixed [1]. While the transportation, inventory, and information sharing decisions can be rapidly re-optimized based on the changes in the parameters of a distribution network, facility location decisions are difficult to change even in the intermediate term. Ineffective decisions in the facility locations can result in excessive costs and poor service level regardless from how well the quality of the product itself. Therefore, facility location decisions play a vital role in designing operations in an efficient distribution network [2].

Facility location problems generally deal with the determination of the optimal number, capacity, type and location of facilities in a geographical area [3]. The aim is to minimise the transportation cost as well as the construction cost while satisfying the customer demand [4]. Operating costs [5], the number of covered demand points [6] and maximum travel time [7] are also optimized in these problems [8].

It is observed in the literature that the location analysis and network design problems have emerged as two major research
Öz

Bu çalıșma, depolardan coğrafi olarak dağınık askeri birliklere dağıtım ağı tasarımını dikkate alarak mühimmat depolarının yer seçimi problemi konusunu ele almaktadır. Burada problem, aday bölgelerden hangilerine mühimmat depoları kurulacağını belirlemek ve hangi tip depolardan kaç adet inşa edileceğine karar vermektir. Ele alınan problem aynı zamanda mühimmat depolarından askeri birliklere sevk edilen pek çok askeri malzemenin miktarını belirlemek için bir dağıtım ağı tasarımı problemini içermektedir. Depo kurulumundan ve farklı askeri malzemelerin depolardan askeri birliklere farklı miktarlarda dağıtımından kaynaklanan toplam maliyeti minimize etmek için bir matematiksel model önerilmektedir. Bu model akabinde asamalı olarak iyileștirilmekte ve gerçek hayat koșullarını bir uygulama vasıtasıyla daha iyi yansitmak amaciyla modelin farklı versiyonları sunulmaktadır. Uygulamaya konu problem, önerilen modellerin GAMS (Genel Cebirsel Modelleme Sistemi)'te kodlanmasıyla çözülerek sayısal örnekler ortaya koyulmuștur. Probleme özgü parametrelerin büyüklügünün model uygulama süresi üzerindeki etkisi de deneysel testlerle incelenmiștir. Sonuçlar, önerilen modellerin pratikte uygulanabilecek umut verici problem çözme kapasitesini göstermektedir.

Anahtar kelimeler: Yer belirleme, Dağıtım ağı tasarımı, Yöneylem araștırması, Karıșı tamsayılı programlama

areas in network optimization [9]. There has been extensive research on facility location and network design problems, individually. That is because designing an effective transportation network involving various decisions such as where to locate facilities and which services to select is a very complex problem [10]. Although these two classes of NP-Hard problems have received considerable attentions as in facility location and network design problems [11], they were optimized separately [12]. On the other hand, the missing link between these two close-related problems has been addressed by many authors recently. This is because, the design strategy of a distribution network tightly influences the optimal allocation of facilities in terms of the transportation costs [13]. In addition to the facility construction costs in a distribution network, the transportation costs must also be optimized. It may be more effective to optimize the distribution network than adding a new facility in terms of their contribution to the objective value. Moving from that point, Daskin et al. [14] introduced the uncapacitated facility location/network design problem (UFLNDP). This is useful because combined facility location/network design problems consist of modelling a number of situations in which trade-offs between facility costs, 
network design costs and operating costs are made. Contributing to this view, Berman et al. [15] proposed that modifying the underlying network can improve the accessibility to the facilities. Similarly, Peeters and Thomas [16] showed the significant impact of underlying network on optimal solutions to the p-median location-allocation problems.

The UFLNDP assumes an infinite capacity for facilities, so that they can serve an infinite amount of demand. However, this assumption may not be valid in situations in which it is not known in advance that the facilities will serve significantly below their capacity. Within this context, the main assumption of the UFLNDP, the infinite capacity of facilities, was restricted and Melkote and Daskin [17] introduced the capacitated facility location/network design problems (CFLNDP).

This research aims at addressing the combined facility location and network design problems in the distribution of various military equipment from ammunition stores to army forces.

The remainder of this paper is organised as follows. The literature is reviewed in Section 2. Section 3 defines the ammunition store location and distribution network design problem and proposes a mixed-integer linear programming approach. Section 4 provides a case study consisting of several candidate sites, army forces, store types and equipment types. The solution of the problem obtained through solving the model via CPLEX available in GAMS is also presented in the same section. Section 5 analyses the model provided and presents several improvements with integrated inequalities to represent more practical real-world conditions. The effect of the problem-specific parameters on the execution time needed by CPLEX is investigated through experimental tests. Finally, the paper is concluded with several future research directions in Section 6.

\section{Literature review}

Due to the NP-hard nature of the CFLNDP, several heuristics and metaheuristics have been proposed in the literature. Drezner and Wesolowsky [18] proposed a model and metaheuristic algorithms based on simulated annealing, tabu search and genetic algorithm to optimize the location of a single facility on a network with a set of candidate links. Cocking [19] also considered the capital constraint and solved the budget constrained UFLNDP using both heuristic and exact approaches. Simple greedy heuristics, a local search heuristic, metaheuristics including simulated annealing and variable neighbourhood search, as well as a custom heuristic were developed by Cocking [19] based on the problem-specific structure of FLNDP. Another budget constrained model was developed by Ghaderi and Jabalameli [20] considering a budget constraint on investment for opening the facilities and constructing links through a case study of health care. They have also proposed a greedy heuristic and a fix-and-optimize heuristic based on simulated annealing and branch \& bound \& cutting method to solve the model. Another real-world problem was also presented and solved by Murawski and Church [21], who introduced the maximal covering network improvement problem. The problem addresses to the problem of improving accessibility to health services keeping the existing facilities location fixed but upgrading the transportation network. Bigotte et al. [22] proposed a mixed-integer optimization model for integrated urban hierarchy and transportation network planning to maximize accessibility to all classes of facilities. A new facility location and network design model was proposed by Contreras et al. [23]. The model aimed at minimizing the maximum travel time in the network. Contreras and Fernández [9] provided alternative formulations and algorithmic strategies for the combined design decisions to locate facilities and to select links on an underlying network. Afshari et al. [24] aimed at optimizing facility location decisions in distributionservice network to maximise profitability while meeting customer satisfaction and sustainability. Bilir et al. [25] addressed to the integrated multi-objective supply chain network and competitive facility location model to maximise profits and sales while minimizing the risks assuming that the demand can be determined by price and the utility function. Interested reader may refer to the surveys on transportation network design problems [26], multi-level facility location problems [27] and covering problems in facility location [28].

Regarding the supply of ammunition or military equipment, one of the early attempts belongs to Staniec [29] who planned the distribution of multiple commodities in a capacitated network through a resource-directive network optimization algorithm. Saunders-Newton [30] defined the adaptive distribution concept in terms of three variant forms, as well as a comparison distribution concept characterized by robustness. The research results showed that a system characterized by an ability to adapt is better suited to the dynamic environments of the future. Hancock and Lee [31] examined the issues affecting the ammunition supply chain within transportation system and provided recommendations to improve the transportation of ammunition. Bell [32] studied the joint problem of facility location and resource allocation to locate munitions storage facilities and inventories for the US Air Force to improve the support of future potential missions. Gue [33] proposed a dynamic distribution model for combat logistics with the objective of minimizing the total inventory of land-based support units. The locations of the support units, inventories held by the units and the amounts shipped between the units are among the decisions made. Powell [34] analysed the problem of finding an optimal mix of combat logistics force shuttle ships required to sustain the sea-base. Clark [35] addressed to the problem of scheduling ammunition transportation through a time-space network representation of the distribution system. A large-scale optimization-based planning method was presented for this aim. Lenhardt [36] provided an evaluation of the concepts on how to best use the marine corps resources to transport water, fuel and ammunition supplies to regimental combat teams over constrained networks with time constraints. Toyoglu et al. [37] developed a mobile ammunition distribution system to provide an effective and flexible distribution system on the battlefield. A static mixed integer programming formulation was developed and several valid inequalities were derived to lessen the solution time and solve several problem instances. Karatas et al. [38] provided a recent review of the literature on military facility location problems.

In the review of the literature presented above, it was observed that the research on the joint facility location and distribution network problem is very limited. While the research on the distribution of military equipment is not as high as desired, to the best of the authors' knowledge, there is no proper research on the ammunition store facility location and distribution network design problem.

Our paper differentiates from the literature in several aspects. Firstly, the combined ammunition store location and distribution network design problem is defined with the 
possibility of constructing different kinds of ammunition stores at a construction site. A combination of different kinds of stores, each of which has a different capacity for storage and needs a certain budget for construction, can be built at a candidate construction site to meet demands by army forces in diverse quantities. Secondly, as will be presented in Figure 1, demands by army forces for certain quantities of diverse equipment can be fulfilled by a mix of shipments from more than one ammunition store. Furthermore, mixed-integer programming models presented in the paper integrate multiple objectives, i.e. the minimization of construction and transportation costs, under many sequential realistic constraints.

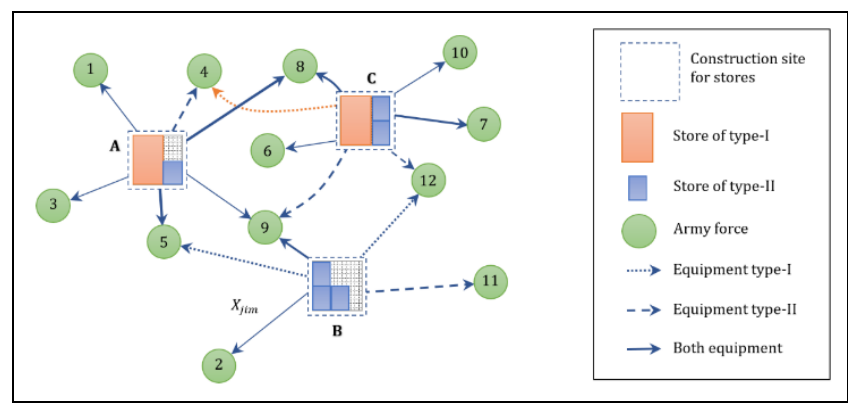

Figure 1: The generic representation of the studied problem.

\section{Problem definition}

The two tightly interrelated problems, namely facility location problem and distribution network design problem (both of which are known NP-hard), are handled together in this research. There is a total of $n j$ candidate sites, where $j=1,2, \ldots, n j$ and $j \in J$, to locate ammunition stores. At each candidate site, ammunition stores can be built in different types $(k=1,2, \ldots, n k$ and $k \in K)$. Each type of ammunition store has a certain construction cost $\left(\mu_{k}\right)$ and total capacity $\left(C P_{k}\right)$ known in advance. So that, more than one ammunition store can be located at each candidate site to serve army forces $(i=$ $1,2, \ldots, n i$ and $i \in I)$ dispersed geographically. Ammunition store sites (or ammunition stores shortly) will supply different equipment types $(m=1,2, \ldots, n m$ and $m \in M)$ to the army forces, so that the demand for equipment type $m$ by army force $i$, represented by $D_{i m}$, is satisfied. The demand by an army force $(i)$ can be met by more than one ammunition store $(j)$ based on its capacity. The delivery cost per unit (ton) of equipment type $m$ from ammunition store located at site $j$ to army force $i$ is calculated as $\alpha_{j i} \times \beta_{m} \times \delta$. In this equation, $\alpha_{j i}$ represents the distance from ammunition store $j$ to army force $i$ (in $\mathrm{km}$ ); $\beta_{m}$ represents the constant index to deliver per unit (ton) of ammunition type $m$, and $\delta$ is the cost to transport per unit of ammunition (any type) for one $\mathrm{km}(\$ / \mathrm{km})$.

Figure 1 illustratively presents the concept model for the studied problem. As seen from the figure, there are three ammunition store sites (A, B and C) including various combinations of stores, i.e. type-I and/or type-II. These stores deliver two kinds of equipment to 12 army forces dispersed geographically. Each army force can be served by one or more stores to meet its demand for different equipment types. For example, all ammunition stores (A, B and C) deliver equipment to meet the demand by army force 9 . While $\mathrm{A}$ and $\mathrm{B}$ transport both equipment to army force 9, C delivers only equipment type-II to that army force. In the figure, the width of the line between the stores and the army forces corresponds to the volume of the transportation. For example, the transportation volume from A to 8 is larger than that from the same store to 1.
The main assumptions and the mathematical model of the problem are presented in the following subsections.

\subsection{Assumptions}

The assumptions of the problem studied are listed as follows.

- The demands for equipment are known and deterministic within the planning horizon considered,

- The construction cost for each type of ammunition store is known and the same for any candidate site,

- The total capacity of each ammunition store is known and deterministic,

- Only one kind of transportation is considered, there are no alternatives like airway or railway,

- There is no difference between different equipment in terms of the storage space. Only the weight of the equipment is considered in terms of the capacity limitation of an ammunition store,

- Ammunition stores can be located to candidate sites in a mixed way. For example, 3 ammunition stores of type- 2 and 2 ammunition stores of type- 3 can be located at a candidate site $j$. So that the total capacity of site $j$ can be calculated as $3 \times C_{2}+2 \times C P_{3}$ and the construction cost for site $j$ can be calculated as $3 \times \mu_{2}+2 \times \mu_{3}$ (using the expression $\sum_{k \in K} C P_{k} Y_{j k}$ ).

- Vehicle routing problem is not considered in the model.

As different from the classical p-median, p-centre and maximal covering problems, the demand from an army force for an equipment can be met by more than one ammunition store. That requires a decision variable $(\geq 0)$ to hold the value of the transportation amount from a specific ammunition store to a certain army force, which extends the search space of the solution.

\subsection{Mathematical model}

A mixed-integer linear programming model is proposed for solving the problem described above. The notations and parameters are presented as follows.

\subsubsection{Notation}

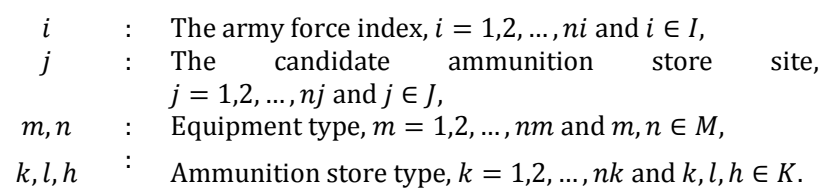

\subsubsection{Parameters}

$D_{i m} \quad$ : The demand for equipment type $m$ by army force $i$ within the planning horizon,

$\mu_{k} \quad$ : The construction cost for ammunition store of type $k$ (\$),

$C P_{k} \quad: \quad$ The total capacity for ammunition store of type $k$ (ton),

$\alpha_{j i} \quad: \quad$ The distance from ammunition store $j$ to army force $i$ $(\mathrm{km})$,

$\beta_{m} \quad$ : The constant index to deliver per unit (ton) of equipment type $m$,

$\delta \quad: \quad$ The cost to transport per unit equipment (any type) for one $\mathrm{km}(\$ / \mathrm{km})$,

$L \quad$ : A large positive number,

$\varphi \quad$ : The maximum number of ammunition stores that can be constructed at a candidate site,

$P_{h} \quad$ : The required minimum proportion of the total capacity of ammunition stores among all stores constructed, 


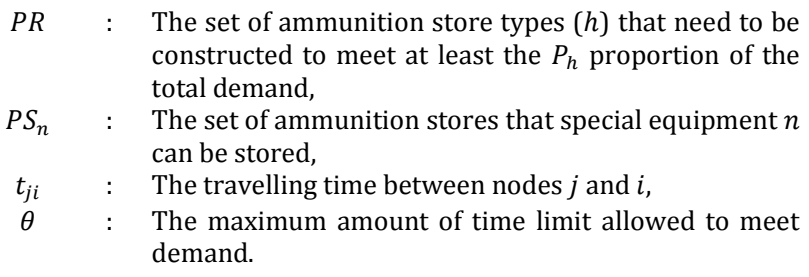

\subsubsection{Decision variables}

The model aims to decide the number of ammunition depots of type $k$ constructed at site $j$ and the amount of each equipment type to be transported from each ammunition store constructed to each army force.

$$
\begin{array}{ll}
X_{j i m}: \quad \begin{array}{l}
\text { The amount of equipment type } m \text { to be transported } \\
\text { from ammunition store } j \text { to army force } i, X_{j i m} \geq 0
\end{array} \\
Y_{j k}: \quad \begin{array}{l}
\text { The number of ammunition store } k \text { constructed at site } \\
j, Y_{j k} \geq 0 .
\end{array}
\end{array}
$$

\subsubsection{Indicators}

$V_{j i} \quad: \quad$ The binary variable to hold the information whether there is equipment transported from store $j$ to army force $i$, where $V_{j i}=\left\{\begin{array}{cc}1 & \sum_{m \in M} X_{j i m}>0 \\ 0 & \text { otherwise }\end{array} \quad \forall j \in J, \quad i \in I\right.$.

\subsubsection{Objective function}

The objective function presented in Equation (1) aims to minimise the sum of ammunition store construction cost and the transportation cost (from ammunition stores to army forces for all ammunition types).

$$
\operatorname{Min} Z=\sum_{j \in J} \sum_{k \in K} \mu_{k} Y_{j k}+\sum_{j \in J} \sum_{i \in I} \sum_{m \in M} \alpha_{j i} \beta_{m} \delta X_{j i m}
$$

\subsubsection{Constraints}

The first constraint, presented in Equation (2), ensures that an ammunition store site can serve an army force if there is at least one store constructed (in any type) at candidate site $j$. Therefore, the expression given here adjusts the status of the two decision variables according to each other.

$$
\sum_{i \in I} \sum_{m \in M} X_{j i m} \leq L \sum_{k \in K} Y_{j k} \quad \forall j \in J
$$

The second constraint, Equation (3), satisfies the capacity constraint for each candidate site. The total amount of equipment transported from an ammunition store $j$ cannot exceed the sum of capacities of ammunition stores (in any type) constructed in ammunition store site $j$.

$$
\sum_{i \in I} \sum_{m \in M} X_{j i m} \leq \sum_{k \in K} C P_{k} Y_{j k} \quad \forall j \in J
$$

The demand of every army force for each equipment type must be met by transportation from ammunition store sites, see Equation (4). In other words, the total amount of equipment type $m$ transported from ammunition stores to army force $i$ must be greater than or equal to the demand for equipment type $m$ by army force $i$.

$$
D_{i m} \leq \sum_{j \in J} X_{j i m} \quad \forall i \in I, m \in M
$$

Due to the physical limitations of the candidate sites, up to a certain number of ammunition stores (in any type) can be constructed at each site. Equation (5) satisfies that total number of ammunition stores constructed at a site does not exceed the maximum limit allowed, $\varphi$.

$$
\sum_{k \in K} Y_{j k} \leq \varphi \quad \forall j \in J
$$

Finally, the sign constraints for decision variables are presented in Equation (6).

$$
Y_{j k}, X_{j i m} \geq 0 \quad \forall j \in J, i \in I, m \in M, k \in K
$$

It should be noted here that the both decision variables $\left(X_{j i m}\right.$ and $Y_{j k}$ ) can get positive values, which makes the problem even harder to solve. On one hand, $Y_{j k}$ is not a binary variable and it can get inbounded integer values which indicates the number of ammunition stores of type $k$ constructed at candidate site $j$. On the other hand, different from a simple maximal covering or p-median problem, $X_{j i m}$ determines the amount of a certain equipment type from a certain supplying site to a certain demanding unit. So that, some army forces can fulfil their demand for certain equipment types from a mixture of more than one ammunition store built in a certain type.

\section{Case study}

In this section, a case study is conducted to show the validity of the model proposed in the previous section and to demonstrate its practicality. The following subsections present the data used for the case study and the results obtained from solving the problem using the model proposed in Section 3.2.

\subsection{Input data}

The data used for the case study is retrieved from the open sources of the military forces as much as possible (e.g. the capacity and costs for constructing different types of ammunition stores, equipment types and the cost to transport them). The candidate sites for ammunition stores and the locations for army forces are generated as in Figure 2 considering a generic map on a sample territory. Note that the exact locations are not provided, instead, the actual travelling distances will be provided later. The demands for equipment by army forces are generated by the authors respecting to the realistic needs of different sized army forces.

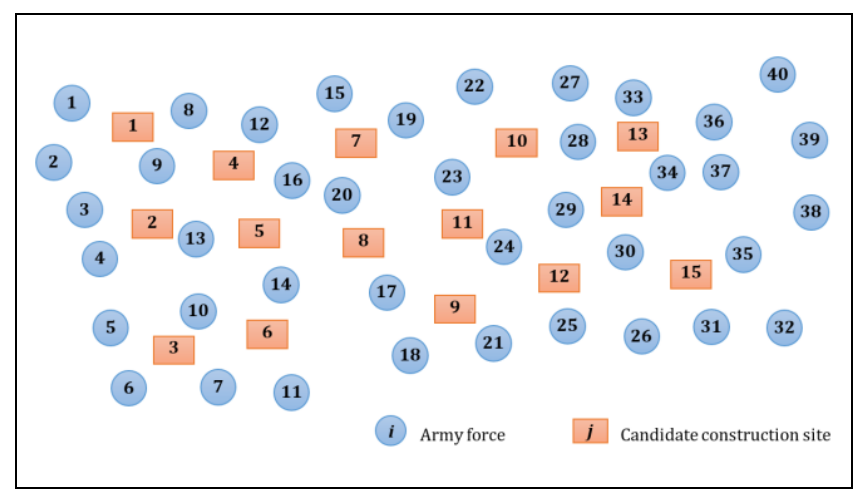

Figure 2: The representation of army forces and candidate sites for ammunition stores.

The distance matrix which shows the travelling distance $(\mathrm{km})$ between candidate sites and army forces $\left(\alpha_{j i}\right)$ is presented in Table 1. 
Table 1: The distance matrix $(\mathrm{km})$.

\begin{tabular}{|c|c|c|c|c|c|c|c|c|c|c|c|c|c|c|c|c|c|c|c|c|}
\hline $\mathrm{j} / \mathrm{i}$ & 1 & 2 & 3 & 4 & 5 & 6 & 7 & 8 & 9 & 10 & 11 & 12 & 13 & 14 & 15 & 16 & 17 & 18 & 19 & 20 \\
\hline 1 & 211 & 230 & 318 & 563 & 683 & 782 & 716 & 216 & 389 & 594 & 937 & 506 & 492 & 453 & 733 & 261 & 775 & 944 & 1091 & 452 \\
\hline 2 & 564 & 583 & 426 & 332 & 408 & 430 & 363 & 275 & 228 & 241 & 665 & 559 & 139 & 100 & 732 & 320 & 436 & 672 & 1070 & 311 \\
\hline 3 & 707 & 690 & 482 & 224 & 126 & 145 & 220 & 560 & 287 & 150 & 691 & 722 & 150 & 222 & 895 & 605 & 518 & 758 & 1233 & 474 \\
\hline 4 & 358 & 377 & 431 & 485 & 605 & 636 & 569 & 69 & 311 & 447 & 790 & 359 & 345 & 306 & 586 & 114 & 628 & 797 & 944 & 305 \\
\hline 5 & 535 & 554 & 423 & 410 & 477 & 499 & 423 & 246 & 303 & 301 & 680 & 481 & 217 & 144 & 654 & 291 & 451 & 687 & 992 & 233 \\
\hline 6 & 873 & 892 & 749 & 549 & 532 & 554 & 322 & 501 & 551 & 314 & 348 & 460 & 338 & 223 & 591 & 456 & 119 & 355 & 850 & 258 \\
\hline 7 & 741 & 760 & 739 & 661 & 680 & 702 & 567 & 314 & 619 & 504 & 467 & 211 & 450 & 339 & 338 & 269 & 364 & 474 & 676 & 75 \\
\hline 8 & 891 & 910 & 866 & 691 & 674 & 696 & 462 & 468 & 693 & 457 & 257 & 417 & 480 & 365 & 502 & 423 & 211 & 264 & 702 & 225 \\
\hline 9 & 1242 & 1261 & 1185 & 985 & 966 & 938 & 627 & 819 & 987 & 749 & 156 & 768 & 774 & 659 & 733 & 774 & 376 & 87 & 789 & 576 \\
\hline 10 & 1101 & 1120 & 1103 & 1025 & 1022 & 1044 & 810 & 674 & 983 & 805 & 492 & 474 & 814 & 703 & 337 & 629 & 496 & 423 & 354 & 439 \\
\hline 11 & 985 & 1004 & 961 & 847 & 830 & 852 & 618 & 558 & 841 & 613 & 325 & 455 & 636 & 521 & 453 & 513 & 304 & 332 & 548 & 319 \\
\hline 12 & 1412 & 1431 & 1388 & 1233 & 1214 & 1186 & 875 & 985 & 1235 & 997 & 404 & 882 & 1022 & 907 & 752 & 940 & 624 & 335 & 683 & 746 \\
\hline 13 & 1378 & 1397 & 1451 & 1401 & 1398 & 1420 & 1168 & 951 & 1331 & 1181 & 697 & 751 & 1190 & 1079 & 577 & 906 & 872 & 628 & 264 & 815 \\
\hline 14 & 1247 & 1266 & 1320 & 1270 & 1270 & 1292 & 1058 & 820 & 1200 & 1053 & 740 & 620 & 1059 & 948 & 446 & 775 & 744 & 671 & 133 & 684 \\
\hline 15 & 1640 & 1659 & 1642 & 1519 & 1500 & 1472 & 1161 & 1213 & 1521 & 1283 & 690 & 1013 & 1308 & 1193 & 876 & 1168 & 910 & 621 & 580 & 978 \\
\hline & 21 & 22 & 23 & 24 & 25 & 26 & 27 & 28 & 29 & 30 & 31 & 32 & 33 & 34 & 35 & 36 & 37 & 38 & 39 & 40 \\
\hline 1 & 1114 & 1064 & 639 & 1110 & 1251 & 1424 & 1139 & 884 & 1176 & 1329 & 1602 & 1791 & 1300 & 1418 & 1501 & 1427 & 1226 & 1636 & 1406 & 1409 \\
\hline 2 & 884 & 1063 & 31 & 952 & 1021 & 1209 & 1 & 883 & 1044 & 1197 & 1392 & 1581 & 99 & 1295 & 1378 & 1394 & 1193 & 1513 & 1373 & 1408 \\
\hline 3 & 970 & 1226 & 644 & 1043 & 1107 & 1295 & 1301 & 1046 & 1141 & 1283 & 1478 & 1667 & 1462 & 1390 & 1473 & 1538 & 1337 & 1608 & 1517 & 1562 \\
\hline 4 & 967 & 917 & 492 & 963 & 1104 & 1277 & 992 & 737 & 1029 & 1182 & 1455 & 1644 & 1153 & 1271 & 1354 & 1280 & 1079 & 1489 & 1259 & 1262 \\
\hline 5 & 878 & 985 & 403 & 874 & 1015 & 1203 & 1060 & 805 & 966 & 1119 & 1386 & 1575 & 1221 & 1217 & 1300 & 1316 & 1115 & 1435 & 1295 & 1330 \\
\hline 6 & 567 & 916 & 258 & 640 & 704 & 892 & 991 & 742 & 738 & 880 & 1075 & 1264 & 1152 & 987 & 1070 & 1135 & 934 & 1205 & 1114 & 1159 \\
\hline 7 & 588 & 669 & 113 & 584 & 725 & 898 & 744 & 489 & 650 & 803 & 1076 & 1265 & 905 & 901 & 984 & 1000 & 799 & 1119 & 979 & 1014 \\
\hline 8 & 476 & 768 & 110 & 492 & 613 & 801 & 843 & 629 & 590 & 741 & 984 & 1173 & 1004 & 839 & 922 & 987 & 786 & 1057 & 966 & 1011 \\
\hline 9 & 125 & 855 & 461 & 309 & 262 & 450 & 930 & 721 & 407 & 438 & 633 & 822 & 949 & 656 & 645 & 927 & 723 & 808 & 879 & 956 \\
\hline 10 & 406 & 420 & 325 & 246 & 499 & 534 & 495 & 312 & 286 & 439 & 712 & 901 & 656 & 537 & 620 & 639 & 438 & 755 & 618 & 663 \\
\hline 11 & 340 & 614 & 135 & 336 & 477 & 665 & 689 & 480 & 434 & 585 & 848 & 1037 & 850 & 683 & 766 & 833 & 632 & 901 & 812 & 857 \\
\hline 12 & 150 & 784 & 562 & 187 & 112 & 298 & 859 & 727 & 285 & 207 & 476 & 665 & 757 & 464 & 414 & 735 & 531 & 577 & 648 & 764 \\
\hline 13 & 476 & 365 & 703 & 232 & 443 & 372 & 440 & 456 & 136 & 277 & 512 & 641 & 461 & 251 & 334 & 444 & 243 & 469 & 423 & 468 \\
\hline 14 & 607 & 234 & 573 & 363 & 574 & 503 & 309 & 325 & 267 & 408 & 643 & 772 & 408 & 382 & 465 & 391 & 190 & 600 & 370 & 415 \\
\hline 15 & 409 & 681 & 820 & 349 & 272 & 149 & 756 & 787 & 253 & 100 & 173 & 362 & 603 & 218 & 135 & 568 & 377 & 298 & 369 & 610 \\
\hline
\end{tabular}

The values presented in the table are retrieved from the actual distances between the nodes given on the map. Note that some nodes may be seen closer to each other on the map. However, the actual travelling distance may be longer caused by the geographical conditions of the area. Each candidate site can have up to $\varphi=72$ ammunition stores, regardless from the type of the ammunition store constructed. The capacities and building costs for the three types of ammunition stores are presented in Table 2. Note that the values given in the table are for only one unit of the related ammunition store type.

Table 2: The specifications of the ammunition stores.

\begin{tabular}{cccc}
\hline$k$ & $\begin{array}{c}\text { Ammunition } \\
\text { Store Type }\end{array}$ & $\begin{array}{c}\text { Total Capacity } \\
\text { (ton) }-C P_{k}\end{array}$ & $\begin{array}{c}\text { Construction } \\
\text { Cost }(\$)-\mu_{k}\end{array}$ \\
\hline 1 & Igloo & 500 & 450000 \\
2 & Brick & 450 & 425000 \\
3 & Shed & 410 & 380000 \\
\hline
\end{tabular}

Seven different types of equipment have been considered within the scope of this study. The types and descriptions of equipment are presented in Table 3 together with the constant index to deliver per unit (ton) of equipment type $m$. Table 4 presents the demands $\left(D_{i m}\right)$ by army forces for each equipment type regardless from the site they are stored.

Table 3: The constant delivery index for each equipment type.

\begin{tabular}{ccc}
\hline$m$ & Description & $\beta_{m}$ \\
\hline 1 & Equipment-1 & 0.10 \\
2 & Equipment-2 & 0.15 \\
3 & Equipment-3 & 0.20 \\
4 & Equipment-4 & 0.25 \\
5 & Equipment-5 & 0.30 \\
6 & Equipment-6 & 0.35 \\
7 & Equipment-7 & 0.40 \\
\hline
\end{tabular}




\subsection{Obtained solution (Model-I)}

The model presented in Section 3.2 in Equations (1)-(6) is coded in GAMS 23.0 and solved using the CPLEX solver embedded in GAMS (this model is called Model-I hereafter). The program is run on a PC equipped with Intel ${ }^{\circledR}$ Core $^{\mathrm{TM}} \mathrm{i} 7-6700 \mathrm{HQ}$ CPU @2.60 GHz and 16 GB of RAM using the input data presented above.

The solution (with the objective value of $231,995,744$ ) was retrieved within 17 minutes with the termination code of 'out of storage' message, which is reasonable considering the wide range for the decision variables and so the complexity of the problem. While the solution is not denoted as optimal, it is feasible and the absolute gap between the best possible solution and the obtained solution is only 34,156 (less than $0.02 \%$ ). Table A1 (see Appendices) presents the values of the decision variable $X_{j i m}$, which corresponds to the amount of equipment $(m)$ transported from each ammunition store $(j)$ to each army force $(i)$.
Some values are seen zero, which indicates that no transportation is planned between the corresponding store and army force. For example, it is seen that the need for equipment type 1 by army force 3 is met by the shipments from both ammunition stores 1 and 4 . However, the demands by army force 3 for all the remaining equipment types (i.e. 2-7), are met by transportation from only store 1 .

The number of constructed ammunition stores from each type $(k)$ at each candidate site $(j)$ is presented in Table 5. As seen from the table, the difference between the total capacity of the ammunition stores constructed and the capacity used is very small, which shows the efficiency of the proposed model and the quality of the solution. The relationship between the ammunition stores constructed and the army forces is also illustrated in Figure 3. The stores constructed at candidate sites are grouped into three based on the total capacity they support (i.e. capacity $\geq 20,000 ; 20,000>$ Capacity $\geq 10,000$; and 10,000 $>$ Capacity $\geq 0$ ).

Table 4: The demands by army forces for each equipment type (ton).

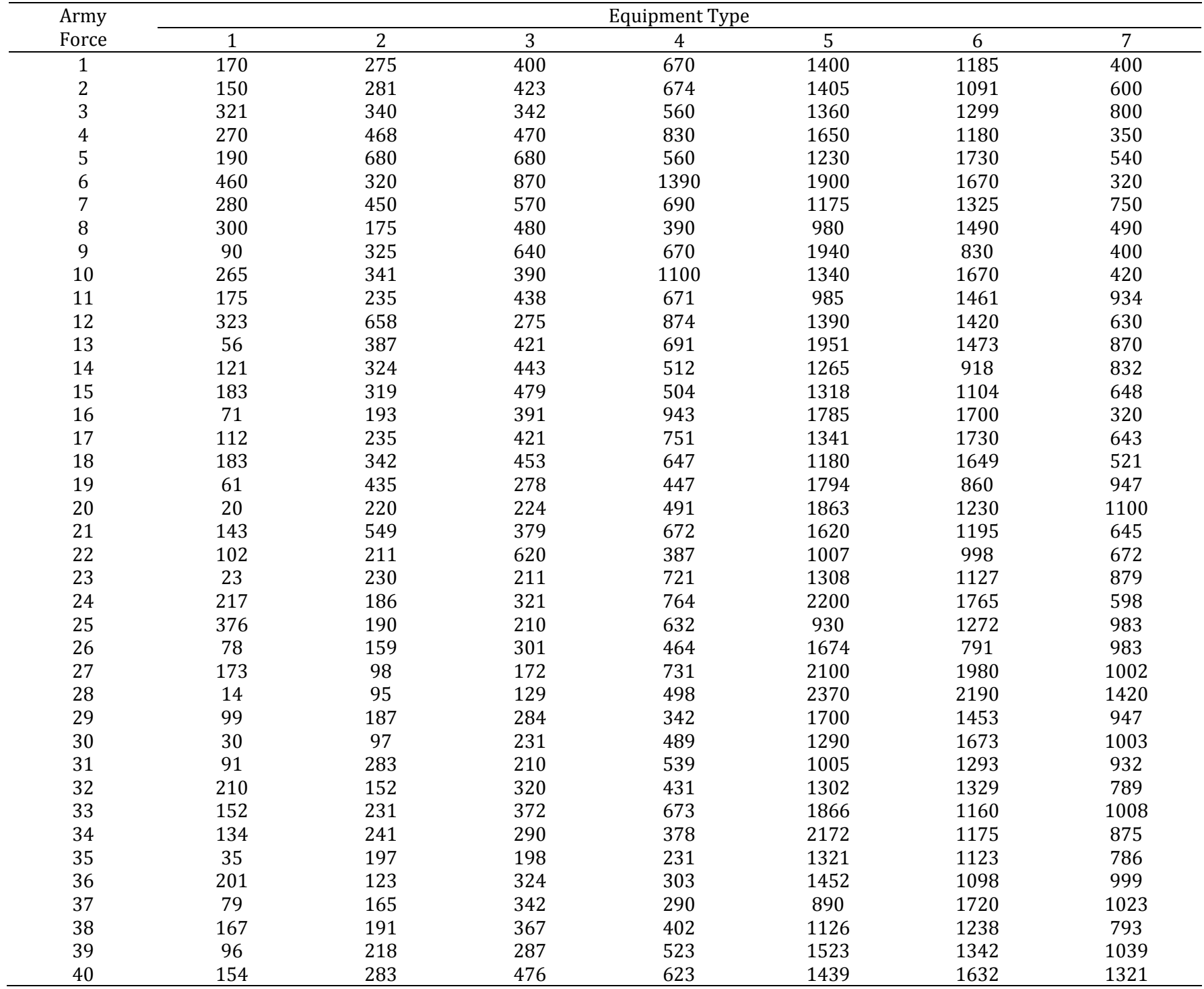


Table 5: The number of constructed ammunition stores at each site (by Model-I).

\begin{tabular}{|c|c|c|c|c|c|c|}
\hline \multirow{2}{*}{$j$} & \multicolumn{3}{|c|}{ The type of ammunition store $(k)$} & \multirow{2}{*}{$\begin{array}{l}\text { Total Capacity } \\
\left(\sum_{k \in K} C P_{k} Y_{j k}\right)\end{array}$} & \multirow{2}{*}{$\begin{array}{c}\text { Capacity Used } \\
\left(\sum_{i \in I} \sum_{m \in M} X_{j i m}\right)\end{array}$} & \multirow{2}{*}{ Utilization } \\
\hline & 1 & 2 & 3 & & & \\
\hline 1 & 28 & - & - & 14,000 & 14,000 & 100.0 \\
\hline 2 & 30 & - & - & 15,000 & 15,000 & 100.0 \\
\hline 3 & 57 & - & - & 28,500 & 28,500 & 100.0 \\
\hline 4 & 19 & - & 1 & 9,910 & 9,910 & 100.0 \\
\hline 6 & 10 & - & 1 & 5,410 & 5,402 & 99.9 \\
\hline 7 & 22 & - & - & 11,000 & 11,000 & 100.0 \\
\hline 8 & 9 & - & - & 4,500 & 4,500 & 100.0 \\
\hline 9 & 30 & - & - & 15,000 & 15,000 & 100.0 \\
\hline 10 & 22 & - & - & 11,000 & 11,000 & 100.0 \\
\hline 12 & 21 & - & - & 10,500 & 10,500 & 100.0 \\
\hline 13 & 9 & - & 2 & 5,320 & 5,320 & 100.0 \\
\hline 14 & 71 & 1 & - & 35,950 & 35,950 & 100.0 \\
\hline 15 & 72 & - & - & 36,000 & 36,000 & 100.0 \\
\hline Total & 400 & 1 & 4 & 202,090 & 202,082 & - \\
\hline
\end{tabular}

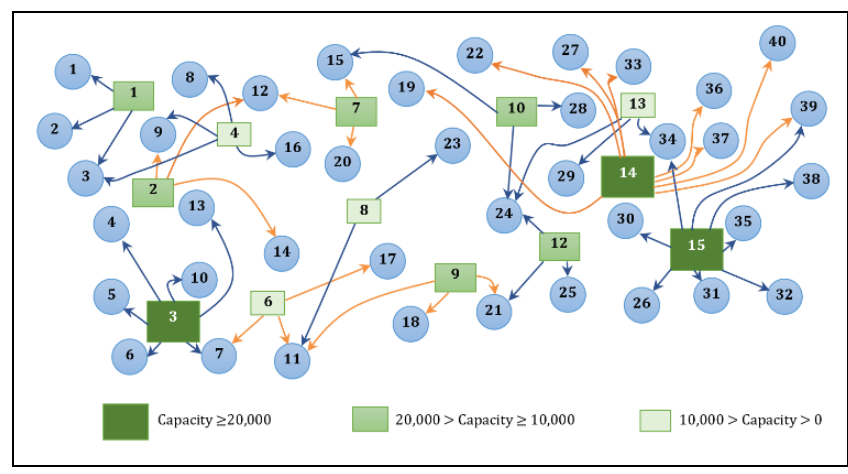

Figure 3: The graphical summary of the distribution network based on Model-I.

The objective value of the solution obtained using Model-I $(231,995,744)$ corresponds to the sum of (i) construction costs of a total of 405 ammunition stores (as presented in Table 5) and the transportation cost of 202,082-ton equipment from the stores constructed at 13 sites to a total of 40 army forces. As seen from the results, no store was constructed at candidate sites 5 and 11.

\section{Model improvements and results}

In this section, the model presented in Section 3.2 is improved to represent some real-world constraints and the problem is solved again under these constraints.

\subsection{Model-II-Minimum ratio for certain ammunition stores}

In some cases, some technological and/or other organisational constraints may require that a certain proportion of total demand met by all ammunition stores must be fulfilled by a certain type of ammunition store. That condition can also be sourced from the security aspects and the use of construction resources. Model-II is built considering a new constraint, see Equation (7), in addition to the Equations (1)-(6) presented in Section 3.2.

$$
\left(\sum_{i \in I} \sum_{m \in M} X_{j i m}\right) P_{h} \leq C P_{h} Y_{j h} \quad \forall j \in J, h \in P R
$$

where $P R$ is the set of ammunition store types $(h)$ that need to be constructed to meet at least the $P_{h}$ proportion of the total demand.

Assume that $P R=\{2\}$ and $P_{2}=0.2$ for the problem given in the previous section. That means at least $20 \%$ of the equipment transported from all sites must be met by ammunition store type 2 . When the problem was solved using Model-II (including the new constraint over Model-I), the optimum solution was obtained within $17 \mathrm{~min}$ as presented in Table A2 and Table 6.

According to the distribution network presented in Figure 4, it is seen that the locations of the major stores (with capacity over 20,000 ton) did not change.

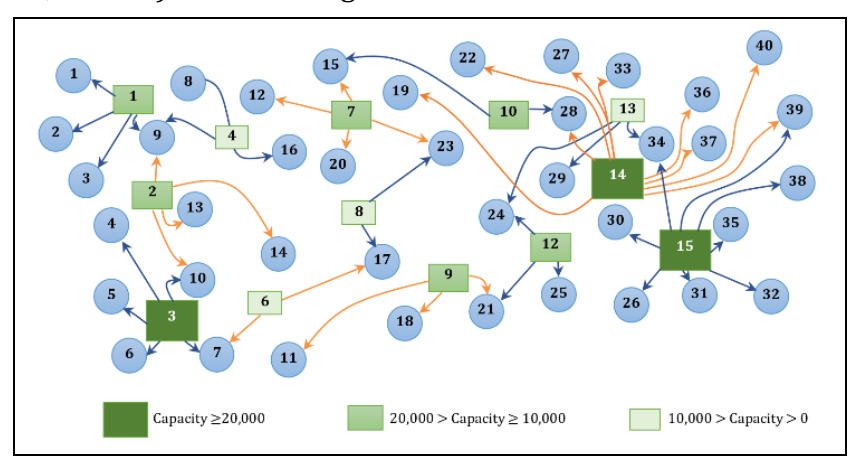

Figure 4: The distribution network obtained based on Model-II.

When the values in Table 6 are investigated, it is seen that the number of stores constructed in all sites was increased from 405 to 414 in comparison to that required by the solution obtained by Model-I. This was mainly due to the constraint (7) included in the model, as it forces the model to open at least $20 \%$ of the ammunition stores from type 2, which has lower capacity than an ammunition store of type 1 . Furthermore, the total cost of the solution obtained also increased to $233,855,757$ based on the increase in the number of stores constructed. The distribution network has also changed with newly opened stores. New transportation links were established between some stores and army forces; see for example, from store 1 to army force 9, from store 2 to army forces 10 and 13, from store 8 to army force 17 , from store 7 to army force 23 and from store 14 to army force 28. 
Table 6: The numbers of ammunition stores constructed (by Model-II).

\begin{tabular}{|c|c|c|c|c|c|c|}
\hline \multirow{2}{*}{$j$} & \multicolumn{3}{|c|}{ The type of ammunition store $(k)$} & \multirow{2}{*}{$\begin{array}{l}\text { Total Capacity } \\
\left(\sum_{k \in K} C P_{k} Y_{j k}\right)\end{array}$} & \multirow{2}{*}{$\begin{array}{l}\text { Capacity Used } \\
\left(\sum_{i \in I} \sum_{m \in M} X_{j i m}\right)\end{array}$} & \multirow{2}{*}{ Utilization } \\
\hline & 1 & 2 & 3 & & & \\
\hline 1 & 22 & 7 & - & 14,150 & 14,150 & 100.0 \\
\hline 2 & 24 & 7 & - & 15,150 & 15,150 & 100.0 \\
\hline 3 & 45 & 13 & - & 28,350 & 28,350 & 100.0 \\
\hline 4 & 15 & 5 & - & 9,750 & 9,750 & 100.0 \\
\hline 6 & 8 & 3 & - & 5,350 & 5,350 & 100.0 \\
\hline 7 & 18 & 5 & - & 11,250 & 11,250 & 100.0 \\
\hline 8 & 7 & 2 & - & 4,400 & 4,400 & 100.0 \\
\hline 9 & 23 & 7 & 1 & 15,060 & 15,060 & 100.0 \\
\hline 10 & 17 & 5 & - & 10,750 & 10,750 & 100.0 \\
\hline 12 & 16 & 5 & 1 & 10,660 & 10,660 & 100.0 \\
\hline 13 & 8 & 3 & - & 5,350 & 5,312 & 99.3 \\
\hline 14 & 61 & 17 & - & 38,150 & 38,150 & 100.0 \\
\hline 15 & 54 & 15 & - & 33,750 & 33,750 & 100.0 \\
\hline Total & 318 & 94 & 2 & 202,120 & 202,082 & - \\
\hline
\end{tabular}

There also were changes in the values of decision variables $X_{j i m}$. For example, all demand by army force 9 for equipment type 1 has been met by stores 2 ( 34 ton) and 4 ( 56 ton) in the solution by Model-I. However, in the solution by Model-II, a small proportion of this demand was met by store 1 . On the other hand, some links were destroyed in the new solution, see for example the links from store 3 to army force 13 , from store 4 to army force 3 , from stores 6 and 8 to army force 11 and from store 10 to army force 24 . In the new situation, at ammunition store 9 , seven stores of type 2 and one store of type 3 were opened instead of seven stores of type 1 . The demand by army force 11 for all equipment types (4899 ton) was met by only store 9 thanks to the help of the increase in the total capacity of store 9 with the newly opened stores of type 2 and type 3 .

\subsection{Model-III-Special equipment requiring special storage}

In real-world applications, some special ammunition types may require a certain type of ammunition store to be stored properly. In such a condition, there should be enough number of certain ammunition stores at a candidate site to meet the demand by army forces for this special equipment. In this environment, following constraint, Equation (8), is included in the model and so Model-III is obtained. Thus, Model-III is constructed from Equations (1)-(8).

$$
\sum_{i \in I} X_{j i n} \leq C P_{l} Y_{j l} \quad \forall j \in J, l \in P S_{n}
$$

Where $P S_{n}$ is the set of ammunition stores that special equipment $n$ can be stored.

The problem whose input data has been given in Section 4 was solved using Model-III. It was assumed that $P S_{2}=\{3\}$, which indicates that if there is equipment type 2 stored at site $j$ it is needed to construct ammunition stores of type 3 for its storage. Also, different from the problem solved in Section 5.1, the values for the parameters $P R$ and $P_{2}$ have been set as follows: $P R=\{2\}$ and $P_{2}=0.1$. That indicates at least $10 \%$ capacity of the constructed ammunition stores must be maintained by ammunition stores of type 2 .
The problem has been solved by CPLEX on the same computer that the previous models have been solved. However, the resource limit was exceeded and the objective value was found $233,327,497$ with an absolute gap of 26,574. Furthermore, changing the 'nodefileind' option to ' 2 ' or ' 3 ', which enables CPLEX to store information on disk (rather than memory), did not help improve the solution capacity. The distribution amounts and constructed ammunition stores belonging to the best solution obtained within $61 \mathrm{~min}$ are presented in Table A3 and Table 7.

The distribution network is drawn as in Figure 5 based on the solution obtained using Model-III.

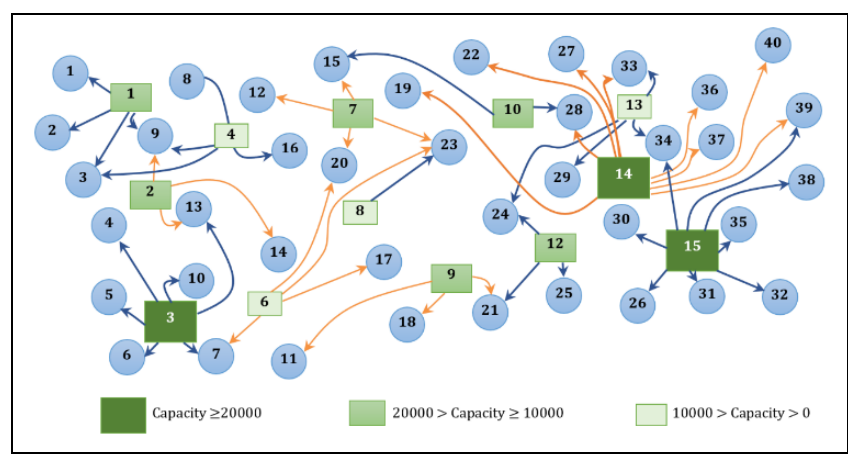

Figure 5: The distribution network obtained based on Model-III.

As seen from the figure, there are many newly established links between ammunition store sites and army forces in comparison to the solution obtained by Model-II; see for example the links between site 2 and army force 3 , site 3 and army force 13 , site 6 and army forces 20 and 23, and site 13 and army force 33 . The only link disappeared is between site 8 and army force 17 . Thus, in the new network, all demand by army force 17 was met by only the shipment from site 6 . Also, new links have been established from site 6 (as mentioned above). In fact, the storage capacity of site 6 was reduced from 5,350 ton to 5,310 ton based on the construction of one store of type 3 instead of one store of type 2 . This became possible with the decrease in the transportation from site 6 to army force 7 . 
Table 7: Constructed ammunition stores at each candidate site (by Model-III).

\begin{tabular}{|c|c|c|c|c|c|c|}
\hline \multirow{2}{*}{$j$} & \multicolumn{3}{|c|}{ The type of ammunition store $(k)$} & \multirow{2}{*}{$\begin{array}{l}\text { Capacity Constructed } \\
\qquad\left(\sum_{k \in K} C P_{k} Y_{j k}\right)\end{array}$} & \multirow{2}{*}{$\begin{array}{c}\text { Capacity Used } \\
\left(\sum_{i \in I} \sum_{m \in M} X_{j i m}\right)\end{array}$} & \multirow{2}{*}{ Utilization } \\
\hline & 1 & 2 & 3 & & & \\
\hline 1 & 23 & 4 & 2 & 14,120 & 14,092 & 99.8 \\
\hline 2 & 24 & 4 & 3 & 15,030 & 15,030 & 100.0 \\
\hline 3 & 46 & 7 & 6 & 28,610 & 28,610 & 100.0 \\
\hline 4 & 16 & 3 & 1 & 9,760 & 9,760 & 100.0 \\
\hline 6 & 8 & 2 & 1 & 5,310 & 5,310 & 100.0 \\
\hline 7 & 21 & 3 & 3 & 13,080 & 13,080 & 100.0 \\
\hline 8 & 7 & 1 & 1 & 4,360 & 4,360 & 100.0 \\
\hline 9 & 24 & 4 & 3 & 15,030 & 15,030 & 100.0 \\
\hline 10 & 16 & 2 & - & 8,900 & 8,900 & 100.0 \\
\hline 12 & 17 & 3 & 2 & 10,670 & 10,670 & 100.0 \\
\hline 13 & 8 & 2 & 1 & 5,310 & 5,310 & 100.0 \\
\hline 14 & 61 & 8 & 4 & 35,740 & 35,740 & 100.0 \\
\hline 15 & 61 & 9 & 4 & 36,190 & 36,190 & 100.0 \\
\hline Total & 332 & 52 & 31 & 202,110 & 202,082 & - \\
\hline
\end{tabular}

Even without the existence of changes in the link establishment, the transportation amounts are optimized with a balance between the construction of new stores. More can be observed when the results in Table A2 and Table A3 are compared.

Notice that the number of stores opened from type 3 was increased from 2 to 31 mainly because of the constraint (8) added in the model for the special storage of ammunition type 2. The contribution of that constraint to the cost of the whole system can easily be seen in the objective function. It should also be noted here that the value of the parameter $P_{2}$ is set to $P_{2}=0.1$ (corresponds to $50 \%$ decrease compared to Model-II) which explains the decrease (from 94 to 52 ) in the number of stores opened from type 2 .

\subsection{Model-IV-Delivery time limit}

Time constraints can be included in the model if there is a condition to supply a demand placed by an army force within a time limit pre-specified. For this aim, the constraints given in Equations (9) and (10) are included in the original Model-I. Thus, Model-IV is composed of Equations (1)-(6) and (9)-(10).

$$
\begin{gathered}
V_{j i} t_{j i} \leq \theta \quad \forall j \in J, i \in I \\
\sum_{m \in M} X_{j i m} \leq V_{j i} L \quad \forall j \in J, i \in I
\end{gathered}
$$

where $t_{j i}$ is the input parameter which indicates the travelling time between nodes $j$ and $i$; $\theta$ is the maximum time limit allowed; and $V_{j i}$ is a binary variable to hold the information whether there is equipment transported from node $j$ to $i$. If the value of $\sum_{m \in M} X_{j i m}$ is greater than $0, V_{j i}$ gets the value of 1 ; and 0 , otherwise.

The problem presented in the Section 4.1 was solved using Model-IV considering the actual transportation times from ammunition store sites to army forces given as input data in Table A4 (see Appendices) and $\theta=500$ minutes. The solution, with the objective value of $231,958,193$ was obtained within 17 minutes with the message that indicates the resource limit was exceeded (the absolute gap was reported as 35,995 ).
The transportation amounts and the number of opened stores at each candidate site are presented in Table A5 and Table 8. The distribution network established based on the results given in the tables is also drawn in Figure 6.

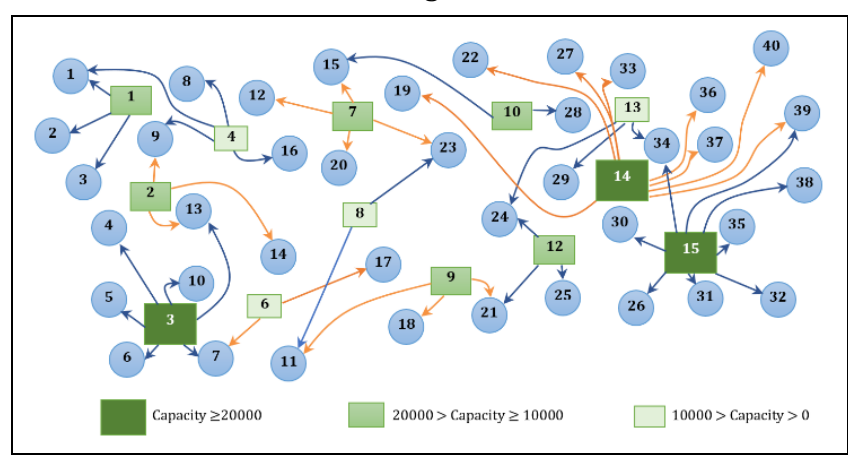

Figure 6: Updated distribution network based on Model-IV.

Since Model-IV is derived from adding new constraints over Model-I, not Model-III, the results obtained in this subsection will be discussed in comparison to the results obtained via Model-I. From the results obtained, the links destroyed between the ammunition store sites and army forces are as follows: from site 2 to army forces 9 and 12 , from site 4 to army force 3 , from site 6 to army force 11 and from site 10 to army force 24 . Basically, the demand by army forces 3 and 12 were met by ammunition store sites within the range of $500 \mathrm{~min}$ travelling distance (site 1 and site 7, respectively), instead of a combined mix including transportations from sites 4 and 2, respectively. The same number of stores are opened in site 1 , i.e. a total of 28 stores from ammunition store type 1 (see Table 5 and Table 8), so the total capacity of the stores at site 1 is the same. However, the cost was balanced and part of the demand by army force 1 was fulfilled via a new link established from site 4. 
Table 8: Ammunition stores constructed at each candidate site (by Model-IV).

\begin{tabular}{|c|c|c|c|c|c|c|}
\hline \multirow{2}{*}{$j$} & \multicolumn{3}{|c|}{ The type of ammunition store $(k)$} & \multirow{2}{*}{$\begin{array}{c}\text { Capacity } \\
\text { Constructed } \\
\left(\sum_{k \in K} C P_{k} Y_{j k}\right)\end{array}$} & \multirow{2}{*}{$\begin{array}{c}\text { Capacity Used } \\
\left(\sum_{i \in I} \sum_{m \in M} X_{j i m}\right)\end{array}$} & \multirow{2}{*}{ Utilization } \\
\hline & 1 & 2 & 3 & & & \\
\hline 1 & 28 & - & - & 14,000 & 14,000 & 100.0 \\
\hline 3 & 57 & - & - & 28,500 & 28,500 & 100.0 \\
\hline 4 & 19 & 1 & - & 9,950 & 9,950 & 100.0 \\
\hline 6 & 9 & - & 2 & 5,320 & 5,320 & 100.0 \\
\hline 7 & 22 & - & - & 11,000 & 10,992 & 99.9 \\
\hline 8 & 9 & - & - & 4,500 & 4,500 & 100.0 \\
\hline 9 & 30 & - & - & 15,000 & 15,000 & 100.0 \\
\hline 10 & 22 & - & - & 11,000 & 11,000 & 100.0 \\
\hline 12 & 21 & - & - & 10,500 & 10,500 & 100.0 \\
\hline 13 & 9 & - & 2 & 5,320 & 5,320 & 100.0 \\
\hline 14 & 71 & - & - & 35,500 & 35,500 & 100.0 \\
\hline 15 & 73 & - & - & 36,500 & 36,500 & 100.0 \\
\hline Total & 400 & 1 & 4 & 202,090 & 202,082 & - \\
\hline
\end{tabular}

Thus, the capacity of site 1 was not exceeded. Similarly, the remaining capacity of site 2 (became empty due to the destroyed link between site 2 and army force 12 as a result of the time limit) was evaluated to supply equipment to army force 13. In the initial solution (obtained by Model-I and presented in Section 4.2), all equipment demanded by army force 13 was met by shipment from only site 3 (which is farther in comparison to site 2).

\subsection{Experimental work}

A set of computational tests has been performed to measure the effect of problem specific parameters on the execution time needed to solve the problem. For this aim, the problem was solved with Model-I using different levels of input parameters, i.e. the number of army forces $(i)$, the number of candidate sites $(j)$, the number of equipment types $(m)$ and the number of ammunition store types $(k)$. The model was run changing the value of only one parameter at a time and the execution time was recorded. The maximum time limit, i.e. the upper bound for the execution time, was set to $3600 \mathrm{~s}$. Any model exceeding that time limit was terminated and the best solution was reported.

Figure 7 shows how execution time was influenced with the change in the above mentioned four parameters. Firstly, as seen in Figure 7(a) the execution time rapidly increased when the number of army forces was increased from 24 to 26 . Interestingly, it slightly reduced with the consideration of 28 and 32 army forces. With the change in the number of army forces from 32 to 36 and 40, the time limit (which was set to $3600 \mathrm{~s}$ ) was exceeded and the program was terminated.

The number of candidate sites has also effect on the size of the search space and so affects the execution time of the model. For this aim, the number of candidate sites has been set to $6,9,12$ and 15 , respectively, and the model was run. The execution time was recorded for each run and plotted as in Figure 7(b). As seen from the figure, there was a dramatical increase in the execution time when the number of candidate sites was changed to 12 . That contributes to the number of decision variables by $3 \times n i \times n m+3 \times k$. That means an extra 849 decision variables (in terms of both $X_{j i m}$ and $Y_{j k}$ ) and a huge increase in the search space. Therefore, the execution time exceeded the $3600 \mathrm{~s}$ time limit.

The number of ammunition types was also one of the main determinants of the execution time of the model. As seen in
Figure $7(c)$, the execution time increased gradually when the number of equipment types was increased. While the execution time was very small when only one type of equipment was considered, the time limit was exceeded when the number of equipment types reached to 6 . This was not surprising as the complexity of the problem increases with a greater number of equipment types. That leads to many new additional decision variables $\left(X_{j i m}\right)$ similar to the situation as in the increase in the number of army forces and the number of candidate sites. Finally, the effect of using different kinds of ammunition stores on the execution time was investigated (see Figure $7(d)$ ). While this does not have a direct effect on the number of $X_{j i m}$ decision variables, it affects the number of $Y_{j k}$ decision variables and influences the interactions between the two decision variables, $X_{j i m}$ and $Y_{j k}$. That also causes an increase in the problem complexity and enlargement of the search space.

\section{Conclusions and future research}

As a nature of the facility location problems, the decisions are intermediate or long term and influence many other decisions on the design of transportation networks, inventory decisions or many other decisions at operational level. The construction of a greater number of facilities will lower the transportation cost as the facilities will tend to be closer to demand locations. However, the total cost will increase due to the construction of new stores. Therefore, there is a trade-off between the construction cost of the new stores and the cost for the transportation from those stores to customers (or demanding points).

The facility location and distribution network design problems, which have close relationship with each other, are usually handled independently. This paper addressed to these tightlyinterrelated problems simultaneously. A mixed-integer linear programming approach is developed and it is progressively improved to represent some realistic constraints, i.e.

i. The use of at least a certain proportion of ammunition stores of a specific kind,

ii. The construction of a specific ammunition store for a certain equipment type, and

iii. The delivery time limit to meet demands. 


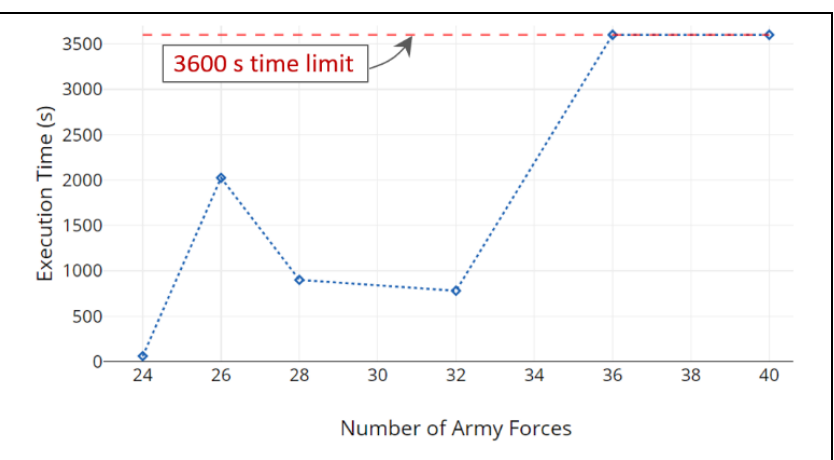

(a)

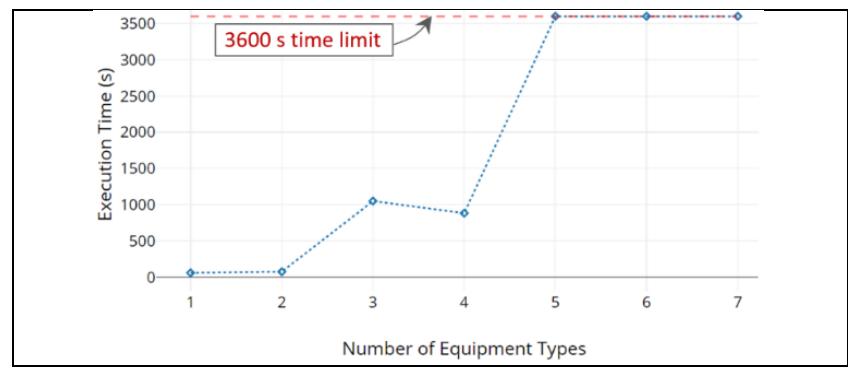

(c)

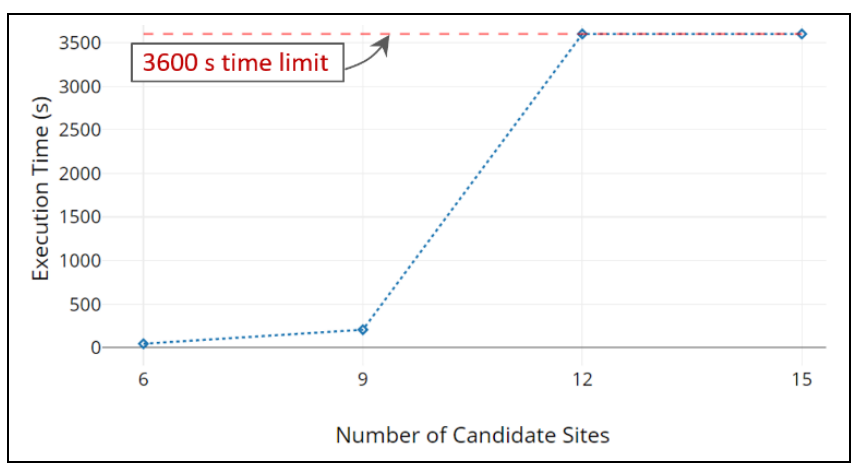

(b)

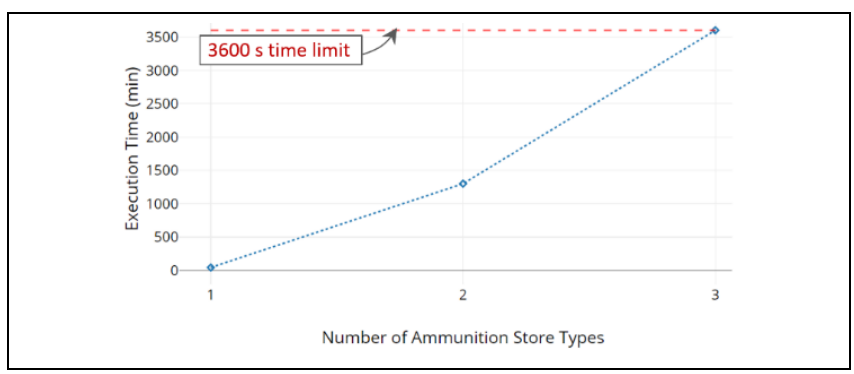

(d)

Figure 7: The effect of parameter levels on the model execution time (in seconds).

The maximum number of stores to be opened at a candidate construction site was also considered in the models. The proposed models aim to minimise the total cost, characterised by the summation of the ammunition store construction costs and the transportation costs for delivery from stores to army forces. More than one type of ammunition store is considered in the models. Their construction costs and total equipment capacities are also different. Thus, a bundle of different stores can be built at a candidate site to meet demand from dispersed army forces at a minimum cost. The optimum solutions are presented where applicable. If the resource limit is exceeded, the best solution obtained so far is presented and discussed for each model and its solution. The results obtained from the models have also been compared to each other with some in depth discussions considering the number of stores opened and the amount of each equipment type shipped to army forces. A set of experimental tests have also been conducted to measure the execution time needed across various levels for the numbers of army forces, candidate sites, different equipment types and ammunition store types. It is observed that the execution time and so the problem complexity increases rapidly with the increase in the size of the parameters except the number of army forces. Interestingly, the increase in the number of army forces from 26 to 28 and 32 does not necessarily affect the execution time in a negative aspect. However, the problem becomes suddenly unsolvable within the $3600 \mathrm{~s}$ time limit when the number of army forces is increased to 36 and 40 .

The methodology and results obtained in this research can be used practically for designing and planning of a new distribution network not only for the shipment of military equipment but also for the transportation of any kind of goods such as automotive parts and electronical devices. While the model presented here assumes that no store exists at the beginning of the planning horizon, the model can be easily modified to adapt to an existing distribution network considering the already constructed storage units. In such a situation, the cost for destroying already existing links between the stores and army forces should also be integrated in the model. One can also aim to minimize the number of changes in the locations of the stores considering a trade-off between the cost of building/destroying a store and the cost for transporting commodities from stores to the demanding units.

The problem and models presented in this research can be extended in several ways. First of all, the assumptions made in the model and discussed above may be relaxed to adapt the proposed model to a wide range of applications. Secondly, the distribution network was considered as a single stage (from ammunition stores to army forces) in this work. A more holistic concept can be studied considering one or more central stores for distribution from centres to stores. Even a direct link can also be built from the centres to the army forces if more efficient in costly manner. Thirdly, the transportation cost considered in the proposed model may not reflect the actual cost as vehicle routing problem has not been considered. Therefore, it would be worthy to include the vehicle routing problem into the distribution network design which also requires some capacitated truck constraints. Last but not least, considering the long-term nature of the facility location decisions, uncertainty in demands can be considered and meta-heuristic models can be developed for the more sophisticated adaptations of the problem.

\section{References}

[1] Klose A. "An LP-based heuristic for two-stage capacitated facility location problems". Journal of the Operational Research Society, 50(2), 157-66, 1999. 
[2] Daskin MS, Snyder LV, Berger RT. Facility Location in Supply Chain Design. Editors: Langevin A., Riopel D. Logistics Systems: Design and Optimization, 39-65, Springer, Boston, MA, 2005.

[3] Drezner T, Drezner Z. "Modelling lost demand in competitive facility location". Journal of the Operational Research Society, 63(2), 201-206, 2012.

[4] Tang X, Lehuédé F, Péton 0. "Location of distribution centers in a multi-period collaborative distribution network". Electronic Notes in Discrete Mathematics, 52, 293-300, 2016.

[5] Kuehn AA, Hamburger MJ. "A heuristic program for locating warehouses". Management Science, 9(4), 643666, 1963.

[6] Church R, Velle CR. "The maximal covering location problem". Papers in Regional Science, 32(1), 101-118, 1974.

[7] Elloumi S, Labbé M, Pochet Y. "A new formulation and resolution method for the p-center problem". INFORMS Journal on Computing, 16(1), 84-94, 2004.

[8] Rahmaniani R, Ghaderi A. "A combined facility location and network design problem with multi-type of capacitated links". Applied Mathematical Modelling 37(9), 6400-6414, 2013.

[9] Contreras I, Fernández E. “General network design: A unified view of combined location and network design problems". European Journal of Operational Research, 219(3), 680-697, 2012.

[10] Rahmaniani R, Ghaderi A. "An algorithm with different exploration mechanisms: Experimental results to capacitated facility location/network design problem". Expert Systems with Applications, 42(7), 3790-3800, 2015.

[11] Crainic TG, Kim KH. Chapter 8 Intermodal Transportation. Editors: Barnhart C, Laporte G. Handbooks in Operations Research and Management Science. 14, 467-537, Elsevier, 2007.

[12] SteadieSeifi M, Dellaert NP, Nuijten W, Van Woensel T, Raoufi R. "Multimodal freight transportation planning: A literature review". European Journal of Operational Research, 233(1), 1-15, 2014.

[13] Melkote S, Daskin MS. "An integrated model of facility location and transportation network design". Transportation Research Part A: Policy and Practice, 35(6), 515-538, 2001.

[14] Daskin MS, Hurter AP, Van Buer MG. "Toward an integrated model of facility location and transportation network design". The Transportation Center, Northwestern University, Working Paper Evanston, IL, USA, 1993.

[15] Berman O, Ingco DI, Odoni AR. "Improving the location of minisum facilities through network modification". Annals of Operations Research, 40(1), 1-16, 1992.

[16] Peeters D, Thomas I. "Effect of spatial structure on pmedian results". Transportation Science, 29(4), 366-373, 1995.

[17] Melkote S, Daskin MS. "Capacitated facility location/network design problems". European Journal of Operational Research, 129(3), 481-495, 2001.

[18] Drezner Z, Wesolowsky GO. "Network design: selection and design of links and facility location". Transportation Research Part A: Policy and Practice, 37(3), 241-256, 2003.

[19] Cocking C. Solutions to Facility Location-Network Design Problems. PhD Thesis, University of Heidelberg, Germany, 2008.
[20] Ghaderi A, Jabalameli MS. "Modeling the budgetconstrained dynamic uncapacitated facility locationnetwork design problem and solving it via two efficient heuristics: A case study of health care". Mathematical and Computer Modelling, 57(3), 382-400, 2013.

[21] Murawski L, Church RL. "Improving accessibility to rural health services: The maximal covering network improvement problem". Socio-Economic Planning Sciences, 43(2), 102-110, 2009.

[22] Bigotte JF, Krass D, Antunes AP, Berman O. "Integrated modeling of urban hierarchy and transportation network planning". Transportation Research Part A: Policy and Practice, 44(7), 506-522, 2010.

[23] Contreras I, Fernández E, Reinelt G. "Minimizing the maximum travel time in a combined model of facility location and network design". Omega, 40(6), 847-860, 2012.

[24] Afshari H, Sharafi M, ElMekkawy T, Peng Q. “Optimizing multi-objective dynamic facility location decisions within green distribution network design". Procedia CIRP, 17, 675-679, 2014.

[25] Bilir C, Ekici SO, Ulengin F. “An integrated multi-objective supply chain network and competitive facility location model". Computers \& Industrial Engineering, 108, 136148, 2017.

[26] Farahani RZ, Miandoabchi E, Szeto WY, Rashidi H. “A review of urban transportation network design problems". European Journal of Operational Research, 229(2), 281-302, 2013.

[27] Ortiz-Astorquiza C, Contreras I, Laporte G. "Multi-level facility location problems". European Journal of Operational Research, 267(3), 791-805, 2018.

[28] Farahani RZ, Asgari N, Heidari N, Hosseininia M, Goh M. "Covering problems in facility location: A review". Computers \& Industrial Engineering, 62(1), 368-407, 2012.

[29] Staniec CJ. Design and Solution of an Ammunition Distribution Model by a Resource-Directive Multi Commodity Network Flow Algorithm. Master's Thesis, Naval Postgraduate School, Monterey, California, 1984.

[30] Saunders-Newton D. Adaptive Battlefield Ammunition Distribution: The Role of Systematic Adaptation in Dynamic Environments. PhD Thesis, RAND Graduate School, Santa Monica, 1993.

[31] Hancock SR, Lee PJ. The Ammunition Supply Chain and Intermodalism: From Depot to Foxhole, Master's Thesis, Naval Postgraduate School, California, 1998.

[32] Bell J. A Simulated Annealing Approach for the Composite Facility Location and Resource Allocation Problem: A Study of Strategic Positioning of US Air Force Munitions, Doctoral Thesis, Auburn University, Auburn, 2003.

[33] Gue KR. "A dynamic distribution model for combat logistics". Computers \& Operations Research, 30(3), 367-381, 2003.

[34] Powell DS. An Optimization Model for Sea-Based Logistics Supply System for the Navy and Marine Corps. Master's Thesis, Naval Postgraduate School, California, 2004.

[35] Clark SJ, Barnhart C, Kolitz SE. "Large-scale optimization planning methods for the distribution of United States army munitions". Mathematical and Computer Modelling, 39(6), 697-714, 2004. 
[36] Lenhardt TA. "Evaluation of a USMC combat service support logistics concept". Mathematical and Computer Modelling, 44(3), 368-376, 2006.

[37] Toyoglu H, Karasan OE, Kara BY. "Distribution network design on the battlefield". Naval Research Logistics, 58(3), 188-209, 2011.
[38] Karatas M, Yakıcı E, Razi N. Military Facility Location Problems: A Brief Survey. Editors: Tozan H, Karatas M. Operations Research for Military Organizations, 1-27, IGI Global, USA, 2019.

Appendices A

Table A1: The amounts of equipment transported from stores to army forces, based on the solution of Model-I.

\begin{tabular}{|c|c|c|c|c|c|c|c|c|}
\hline \multirow{2}{*}{ From $j$} & \multirow{2}{*}{ To $i$} & \multicolumn{7}{|c|}{ Distribution amount of equipment type $m$} \\
\hline & & 1 & 2 & 3 & 4 & 5 & 6 & 7 \\
\hline 1 & 1 & 170 & 275 & 400 & 670 & 1400 & 1185 & 400 \\
\hline 1 & 2 & 150 & 281 & 423 & 674 & 1405 & 1091 & 600 \\
\hline 1 & 3 & 175 & 340 & 342 & 560 & 1360 & 1299 & 800 \\
\hline 2 & 9 & 34 & 325 & 640 & 670 & 1940 & 830 & 400 \\
\hline 2 & 12 & 0 & 340 & 421 & 691 & 1951 & 1473 & 870 \\
\hline 2 & 14 & 121 & 324 & 443 & 512 & 1265 & 918 & 832 \\
\hline 3 & 4 & 270 & 468 & 470 & 830 & 1650 & 1180 & 350 \\
\hline 3 & 5 & 190 & 680 & 680 & 560 & 1230 & 1730 & 540 \\
\hline 3 & 6 & 460 & 320 & 870 & 1390 & 1900 & 1670 & 320 \\
\hline 3 & 7 & 153 & 450 & 570 & 690 & 1175 & 1325 & 750 \\
\hline 3 & 10 & 265 & 341 & 390 & 1100 & 1340 & 1670 & 420 \\
\hline 3 & 13 & 56 & 47 & 0 & 0 & 0 & 0 & 0 \\
\hline 4 & 3 & 146 & 0 & 0 & 0 & 0 & 0 & 0 \\
\hline 4 & 8 & 300 & 175 & 480 & 390 & 980 & 1490 & 490 \\
\hline 4 & 9 & 56 & 0 & 0 & 0 & 0 & 0 & 0 \\
\hline 4 & 16 & 71 & 193 & 391 & 943 & 1785 & 1700 & 320 \\
\hline 6 & 7 & 127 & 0 & 0 & 0 & 0 & 0 & 0 \\
\hline 6 & 11 & 42 & 0 & 0 & 0 & 0 & 0 & 0 \\
\hline 6 & 17 & 112 & 235 & 421 & 751 & 1341 & 1730 & 643 \\
\hline 7 & 12 & 323 & 658 & 275 & 874 & 1390 & 1420 & 630 \\
\hline 7 & 15 & 183 & 99 & 0 & 0 & 0 & 0 & 0 \\
\hline 7 & 20 & 20 & 220 & 224 & 491 & 1863 & 1230 & 1100 \\
\hline 8 & 11 & 1 & 0 & 0 & 0 & 0 & 0 & 0 \\
\hline 8 & 23 & 23 & 230 & 211 & 721 & 1308 & 1127 & 879 \\
\hline 9 & 11 & 132 & 235 & 438 & 671 & 985 & 1461 & 934 \\
\hline 9 & 18 & 183 & 342 & 453 & 647 & 1180 & 1649 & 521 \\
\hline 9 & 21 & 109 & 549 & 379 & 672 & 1620 & 1195 & 645 \\
\hline 10 & 15 & 0 & 220 & 479 & 504 & 1318 & 1104 & 648 \\
\hline 10 & 24 & 11 & 0 & 0 & 0 & 0 & 0 & 0 \\
\hline 10 & 28 & 14 & 95 & 129 & 498 & 2370 & 2190 & 1420 \\
\hline 12 & 21 & 34 & 0 & 0 & 0 & 0 & 0 & 0 \\
\hline 12 & 24 & 39 & 186 & 321 & 764 & 2200 & 1765 & 598 \\
\hline 12 & 25 & 376 & 190 & 210 & 632 & 930 & 1272 & 983 \\
\hline 13 & 24 & 167 & 0 & 0 & 0 & 0 & 0 & 0 \\
\hline 13 & 29 & 99 & 187 & 284 & 342 & 1700 & 1453 & 947 \\
\hline 13 & 34 & 134 & 7 & 0 & 0 & 0 & 0 & 0 \\
\hline 14 & 19 & 61 & 435 & 278 & 447 & 1794 & 860 & 947 \\
\hline 14 & 22 & 102 & 211 & 620 & 387 & 1007 & 998 & 672 \\
\hline 14 & 27 & 173 & 98 & 172 & 731 & 2100 & 1980 & 1002 \\
\hline 14 & 33 & 152 & 231 & 372 & 673 & 1866 & 1160 & 1008 \\
\hline 14 & 36 & 201 & 123 & 324 & 303 & 1452 & 1098 & 999 \\
\hline 14 & 37 & 79 & 165 & 342 & 290 & 890 & 1720 & 1023 \\
\hline 14 & 39 & 96 & 218 & 162 & 0 & 0 & 0 & 0 \\
\hline 14 & 40 & 154 & 283 & 476 & 623 & 1439 & 1632 & 1321 \\
\hline 15 & 26 & 78 & 159 & 301 & 464 & 1674 & 791 & 983 \\
\hline 15 & 30 & 30 & 97 & 231 & 489 & 1290 & 1673 & 1003 \\
\hline 15 & 31 & 91 & 283 & 210 & 539 & 1005 & 1293 & 932 \\
\hline 15 & 32 & 210 & 152 & 320 & 431 & 1302 & 1329 & 789 \\
\hline
\end{tabular}


Table A1: The amounts of ammunition transported from stores to army forces, based on the solution of Model-I.

\begin{tabular}{|c|c|c|c|c|c|c|c|c|}
\hline \multirow{2}{*}{ From $j$} & \multirow{2}{*}{ To $i$} & \multicolumn{7}{|c|}{ Distribution amount of equipment type $m$} \\
\hline & & 1 & 2 & 3 & 4 & 5 & 6 & 7 \\
\hline 15 & 34 & 0 & 234 & 290 & 378 & 2172 & 1175 & 875 \\
\hline 15 & 35 & 35 & 197 & 198 & 231 & 1321 & 1123 & 786 \\
\hline 15 & 38 & 167 & 191 & 367 & 402 & 1126 & 1238 & 793 \\
\hline 15 & 39 & 0 & 0 & 125 & 523 & 1523 & 1342 & 1039 \\
\hline \multicolumn{9}{|c|}{ Table A2: The transportation amounts from ammunition stores to army forces based on the solution of Model-II. } \\
\hline \multirow{2}{*}{ From $j$} & \multirow{2}{*}{ To $i$} & \multicolumn{7}{|c|}{ Distribution amount of equipment type $m$} \\
\hline & & 1 & 2 & 3 & 4 & 5 & 6 & 7 \\
\hline 1 & 1 & 170 & 275 & 400 & 670 & 1400 & 1185 & 400 \\
\hline 1 & 2 & 150 & 281 & 423 & 674 & 1405 & 1091 & 600 \\
\hline 1 & 3 & 321 & 340 & 342 & 560 & 1360 & 1299 & 800 \\
\hline 1 & 9 & 4 & 0 & 0 & 0 & 0 & 0 & 0 \\
\hline 2 & 9 & 44 & 325 & 640 & 670 & 1940 & 830 & 400 \\
\hline 2 & 10 & 37 & 0 & 0 & 0 & 0 & 0 & 0 \\
\hline 2 & 13 & 56 & 387 & 421 & 691 & 1951 & 1473 & 870 \\
\hline 2 & 14 & 121 & 324 & 443 & 512 & 1265 & 918 & 832 \\
\hline 3 & 4 & 270 & 468 & 470 & 830 & 1650 & 1180 & 350 \\
\hline 3 & 5 & 190 & 680 & 680 & 560 & 1230 & 1730 & 540 \\
\hline 3 & 6 & 460 & 320 & 870 & 1390 & 1900 & 1670 & 320 \\
\hline 3 & 7 & 143 & 450 & 570 & 690 & 1175 & 1325 & 750 \\
\hline 3 & 10 & 228 & 341 & 390 & 1100 & 1340 & 1670 & 420 \\
\hline 4 & 8 & 300 & 175 & 480 & 390 & 980 & 1490 & 490 \\
\hline 4 & 9 & 42 & 0 & 0 & 0 & 0 & 0 & 0 \\
\hline 4 & 16 & 71 & 193 & 391 & 943 & 1785 & 1700 & 320 \\
\hline 6 & 7 & 137 & 0 & 0 & 0 & 0 & 0 & 0 \\
\hline 6 & 17 & 92 & 235 & 421 & 751 & 1341 & 1730 & 643 \\
\hline 7 & 12 & 323 & 658 & 275 & 874 & 1390 & 1420 & 630 \\
\hline 7 & 15 & 183 & 230 & 0 & 0 & 0 & 0 & 0 \\
\hline 7 & 20 & 20 & 220 & 224 & 491 & 1863 & 1230 & 1100 \\
\hline 7 & 23 & 23 & 96 & 0 & 0 & 0 & 0 & 0 \\
\hline 8 & 17 & 20 & 0 & 0 & 0 & 0 & 0 & 0 \\
\hline 8 & 23 & 0 & 134 & 211 & 721 & 1308 & 1127 & 879 \\
\hline 9 & 11 & 175 & 235 & 438 & 671 & 985 & 1461 & 934 \\
\hline 9 & 18 & 183 & 342 & 453 & 647 & 1180 & 1649 & 521 \\
\hline 9 & 21 & 126 & 549 & 379 & 672 & 1620 & 1195 & 645 \\
\hline 10 & 15 & 0 & 89 & 479 & 504 & 1318 & 1104 & 648 \\
\hline 10 & 28 & 0 & 1 & 129 & 498 & 2370 & 2190 & 1420 \\
\hline 12 & 21 & 17 & 0 & 0 & 0 & 0 & 0 & 0 \\
\hline 12 & 24 & 216 & 186 & 321 & 764 & 2200 & 1765 & 598 \\
\hline 12 & 25 & 376 & 190 & 210 & 632 & 930 & 1272 & 983 \\
\hline 13 & 24 & 1 & 0 & 0 & 0 & 0 & 0 & 0 \\
\hline 13 & 29 & 99 & 187 & 284 & 342 & 1700 & 1453 & 947 \\
\hline 13 & 34 & 134 & 165 & 0 & 0 & 0 & 0 & 0 \\
\hline 14 & 19 & 61 & 435 & 278 & 447 & 1794 & 860 & 947 \\
\hline 14 & 22 & 102 & 211 & 620 & 387 & 1007 & 998 & 672 \\
\hline 14 & 27 & 173 & 98 & 172 & 731 & 2100 & 1980 & 1002 \\
\hline 14 & 28 & 14 & 94 & 0 & 0 & 0 & 0 & 0 \\
\hline 14 & 33 & 152 & 231 & 372 & 673 & 1866 & 1160 & 1008 \\
\hline 14 & 36 & 201 & 123 & 324 & 303 & 1452 & 1098 & 999 \\
\hline 14 & 37 & 79 & 165 & 342 & 290 & 890 & 1720 & 1023 \\
\hline 14 & 39 & 96 & 218 & 287 & 523 & 1444 & 0 & 0 \\
\hline
\end{tabular}


Table A2: The transportation amounts from ammunition stores to army forces based on the solution of Model-II.

\begin{tabular}{ccccccccc}
\hline \multirow{2}{*}{ From $j$} & To $i$ & \multicolumn{7}{c}{ Distribution amount of equipment type $m$} \\
\cline { 3 - 8 } & & 1 & 2 & 3 & 4 & 5 & 6 & 7 \\
\hline 14 & 40 & 154 & 283 & 476 & 623 & 1439 & 1632 & 791 \\
15 & 26 & 78 & 159 & 301 & 464 & 1674 & 983 & 1673 \\
15 & 30 & 30 & 97 & 231 & 489 & 1290 & 1293 & 932 \\
15 & 31 & 91 & 283 & 210 & 539 & 1005 & 1329 & 789 \\
15 & 32 & 210 & 152 & 320 & 431 & 1302 & 1175 & 875 \\
15 & 34 & 0 & 76 & 290 & 378 & 2172 & 1123 & 786 \\
15 & 35 & 35 & 197 & 198 & 231 & 1321 & 1238 & 793 \\
15 & 38 & 167 & 191 & 367 & 402 & 1126 & 1342 & 1039 \\
15 & 39 & 0 & 0 & 0 & 0 & 79 &
\end{tabular}

Table A3: The amounts of transported equipment obtained from the solution of Model-III.

\begin{tabular}{|c|c|c|c|c|c|c|c|c|}
\hline \multirow{2}{*}{ From $j$} & \multirow{2}{*}{ To $i$} & \multicolumn{7}{|c|}{ Amount of equipment type $m$ to be distributed } \\
\hline & & 1 & 2 & 3 & 4 & 5 & 6 & 7 \\
\hline 1 & 1 & 170 & 275 & 400 & 670 & 1400 & 1185 & 400 \\
\hline 1 & 2 & 150 & 281 & 423 & 674 & 1405 & 1091 & 600 \\
\hline 1 & 3 & 321 & 264 & 342 & 560 & 1360 & 1299 & 800 \\
\hline 1 & 9 & 22 & 0 & 0 & 0 & 0 & 0 & 0 \\
\hline 2 & 3 & 0 & 34 & 0 & 0 & 0 & 0 & 0 \\
\hline 2 & 9 & 58 & 325 & 640 & 670 & 1940 & 830 & 400 \\
\hline 2 & 13 & 0 & 312 & 421 & 691 & 1951 & 1473 & 870 \\
\hline 2 & 14 & 121 & 324 & 443 & 512 & 1265 & 918 & 832 \\
\hline 3 & 4 & 270 & 468 & 470 & 830 & 1650 & 1180 & 350 \\
\hline 3 & 5 & 190 & 680 & 680 & 560 & 1230 & 1730 & 540 \\
\hline 3 & 6 & 460 & 320 & 870 & 1390 & 1900 & 1670 & 320 \\
\hline 3 & 7 & 235 & 450 & 570 & 690 & 1175 & 1325 & 750 \\
\hline 3 & 10 & 265 & 341 & 390 & 1100 & 1340 & 1670 & 420 \\
\hline 3 & 13 & 56 & 75 & 0 & 0 & 0 & 0 & 0 \\
\hline 4 & 3 & 0 & 42 & 0 & 0 & 0 & 0 & 0 \\
\hline 4 & 8 & 300 & 175 & 480 & 390 & 980 & 1490 & 490 \\
\hline 4 & 9 & 10 & 0 & 0 & 0 & 0 & 0 & 0 \\
\hline 4 & 16 & 71 & 193 & 391 & 943 & 1785 & 1700 & 320 \\
\hline 6 & 7 & 45 & 0 & 0 & 0 & 0 & 0 & 0 \\
\hline 6 & 17 & 112 & 235 & 421 & 751 & 1341 & 1730 & 643 \\
\hline 6 & 20 & 9 & 0 & 0 & 0 & 0 & 0 & 0 \\
\hline 6 & 23 & 23 & 0 & 0 & 0 & 0 & 0 & 0 \\
\hline 7 & 12 & 323 & 658 & 275 & 874 & 1390 & 1420 & 630 \\
\hline 7 & 15 & 183 & 319 & 479 & 504 & 770 & 0 & 0 \\
\hline 7 & 20 & 11 & 220 & 224 & 491 & 1863 & 1230 & 1100 \\
\hline 7 & 23 & 0 & 33 & 83 & 0 & 0 & 0 & 0 \\
\hline 8 & 23 & 0 & 197 & 128 & 721 & 1308 & 1127 & 879 \\
\hline 9 & 11 & 175 & 235 & 438 & 671 & 985 & 1461 & 934 \\
\hline 9 & 18 & 183 & 342 & 453 & 647 & 1180 & 1649 & 521 \\
\hline 9 & 21 & 96 & 549 & 379 & 672 & 1620 & 1195 & 645 \\
\hline 10 & 15 & 0 & 0 & 0 & 0 & 548 & 1104 & 648 \\
\hline 10 & 28 & 0 & 0 & 122 & 498 & 2370 & 2190 & 1420 \\
\hline 12 & 21 & 47 & 0 & 0 & 0 & 0 & 0 & 0 \\
\hline 12 & 24 & 196 & 186 & 321 & 764 & 2200 & 1765 & 598 \\
\hline 12 & 25 & 376 & 190 & 210 & 632 & 930 & 1272 & 983 \\
\hline 13 & 24 & 21 & 0 & 0 & 0 & 0 & 0 & 0 \\
\hline 13 & 29 & 99 & 187 & 284 & 342 & 1700 & 1453 & 947 \\
\hline 13 & 33 & 0 & 1 & 0 & 0 & 0 & 0 & 0 \\
\hline 13 & 34 & 134 & 142 & 0 & 0 & 0 & 0 & 0 \\
\hline 14 & 19 & 61 & 435 & 278 & 447 & 1794 & 860 & 947 \\
\hline 14 & 22 & 102 & 211 & 620 & 387 & 1007 & 998 & 672 \\
\hline 14 & 27 & 173 & 98 & 172 & 731 & 2100 & 1980 & 1002 \\
\hline 14 & 28 & 14 & 95 & 7 & 0 & 0 & 0 & 0 \\
\hline
\end{tabular}


Table A3: The amounts of transported equipment obtained from the solution of Model-III.

\begin{tabular}{|c|c|c|c|c|c|c|c|c|}
\hline \multirow{2}{*}{ From $j$} & \multirow{2}{*}{ To $i$} & \multicolumn{7}{|c|}{ Amount of equipment type $m$ to be distributed } \\
\hline & & 1 & 2 & 3 & 4 & 5 & 6 & 7 \\
\hline 14 & 33 & 152 & 230 & 372 & 673 & 1866 & 1160 & 1008 \\
\hline 14 & 36 & 201 & 123 & 324 & 303 & 1452 & 1098 & 999 \\
\hline 14 & 37 & 79 & 165 & 342 & 290 & 890 & 1720 & 1023 \\
\hline 14 & 39 & 96 & 0 & 55 & 0 & 0 & 0 & 0 \\
\hline 14 & 40 & 154 & 283 & 476 & 623 & 1439 & 1632 & 1321 \\
\hline 15 & 26 & 78 & 159 & 301 & 464 & 1674 & 791 & 983 \\
\hline 15 & 30 & 30 & 97 & 231 & 489 & 1290 & 1673 & 1003 \\
\hline 15 & 31 & 91 & 283 & 210 & 539 & 1005 & 1293 & 932 \\
\hline 15 & 32 & 210 & 152 & 320 & 431 & 1302 & 1329 & 789 \\
\hline 15 & 34 & 0 & 99 & 290 & 378 & 2172 & 1175 & 875 \\
\hline 15 & 35 & 35 & 197 & 198 & 231 & 1321 & 1123 & 786 \\
\hline 15 & 38 & 167 & 191 & 367 & 402 & 1126 & 1238 & 793 \\
\hline 15 & 39 & 0 & 218 & 232 & 523 & 1523 & 1342 & 1039 \\
\hline
\end{tabular}

Table A4: Travelling times from ammunition store sites to army forces (in min).

\begin{tabular}{|c|c|c|c|c|c|c|c|c|c|c|c|c|c|c|c|c|c|c|c|c|}
\hline $\mathrm{j} / \mathrm{i}$ & 1 & 2 & 3 & 4 & 5 & 6 & 7 & 8 & 9 & 10 & 11 & 12 & 13 & 14 & 15 & 16 & 17 & 18 & 19 & 20 \\
\hline 1 & 253 & 276 & 382 & 676 & 820 & 938 & 859 & 259 & 467 & 713 & 1124 & 607 & 590 & 544 & 880 & 313 & 930 & 1133 & 1309 & 542 \\
\hline 2 & 677 & & & 398 & 490 & 516 & 436 & 330 & 274 & 289 & & 671 & 167 & 20 & 878 & 84 & 523 & 06 & 284 & 73 \\
\hline 3 & 848 & 828 & 70 & 269 & 151 & 174 & 264 & 672 & 344 & 180 & 829 & 866 & 180 & 266 & 1074 & 726 & 622 & 910 & 1480 & 569 \\
\hline 4 & 430 & & 7 & 582 & 726 & 763 & 683 & 83 & 373 & 536 & 948 & 431 & 414 & 367 & 703 & 137 & 754 & 956 & 1133 & 366 \\
\hline 5 & 642 & 665 & 08 & 492 & 572 & 599 & 508 & 295 & 364 & 361 & 816 & 577 & 260 & 173 & 785 & 349 & 541 & 824 & 1190 & 280 \\
\hline 6 & 1048 & 1070 & 899 & 659 & 638 & 665 & 386 & 601 & 661 & 377 & 418 & 552 & 406 & 268 & 709 & 547 & 143 & 426 & 1020 & 310 \\
\hline 7 & 889 & 912 & 887 & 793 & 816 & 842 & 680 & 377 & 743 & 605 & 560 & 253 & 540 & 407 & 406 & 323 & 437 & 569 & 811 & 90 \\
\hline 8 & 1069 & 10 & & 829 & 809 & 835 & & & 832 & 548 & 8 & 0 & 576 & 8 & 602 & 88 & 53 & 17 & 42 & 270 \\
\hline 9 & 1490 & 1 & 22 & 1182 & 1159 & 1126 & 752 & 983 & 1184 & 899 & 187 & 922 & 929 & 791 & 880 & 929 & 451 & 104 & 947 & 691 \\
\hline 10 & & & & & & & & & & 966 & 590 & 569 & 977 & 44 & & 55 & 595 & 08 & 425 & 527 \\
\hline 11 & 1182 & 1205 & 53 & 1016 & 996 & 1022 & 742 & 670 & 1009 & 736 & 390 & 546 & 763 & 625 & 544 & 616 & 365 & 398 & 658 & 383 \\
\hline 12 & & & & 1480 & 1457 & 1423 & & & & 1196 & 485 & 1058 & 1226 & 1088 & 902 & 1128 & 749 & 402 & 820 & 895 \\
\hline 13 & 1654 & 1676 & 41 & 1681 & 1678 & 1704 & 1402 & 1141 & 1597 & 1417 & 836 & 901 & 1428 & 1295 & 692 & 1087 & 1046 & 754 & 317 & 978 \\
\hline 14 & & & & & & & & 904 & & 1264 & 888 & 744 & 1271 & 1138 & 535 & 930 & 893 & 805 & 160 & 821 \\
\hline \multirow[t]{2}{*}{15} & 1968 & 19 & & 1823 & 1800 & 1766 & 1393 & 1456 & 1825 & 1540 & 828 & 1216 & 1570 & 1432 & 1051 & 1402 & 1092 & 745 & 696 & 1174 \\
\hline & - & & & 24 & & & 27 & & & 30 & & & & 34 & & 36 & & 38 & & 40 \\
\hline 1 & 132 & 1 & & 1 & 1 & 09 & 1 & 1061 & 1411 & 15 & 1922 & 49 & 50 & 1702 & 1 & 1712 & 1 & 1963 & 87 & 1691 \\
\hline 2 & 1061 & 1276 & 577 & 1142 & 1225 & 1451 & 1366 & 1060 & 1253 & 1436 & 1670 & 1897 & 1559 & 1554 & 1654 & 1673 & 1432 & 1816 & 1648 & 1690 \\
\hline 3 & 1164 & 14 & 773 & 1252 & 1328 & 54 & 1561 & 1255 & 1369 & 1540 & 1774 & 2000 & 1754 & 1668 & 1768 & 1846 & 1604 & 1930 & 1820 & 1874 \\
\hline 4 & 1160 & 110 & 590 & 1156 & 1325 & 1532 & 1190 & 884 & 1235 & 1418 & 1746 & 1973 & 1384 & 1525 & 1625 & 1536 & 1295 & 1787 & 1511 & 1514 \\
\hline 5 & 1054 & 1182 & & 1049 & 1218 & 1444 & 1272 & 966 & 1159 & 1343 & 1663 & 1890 & 1465 & 1460 & 1560 & 1579 & 1338 & 1722 & 1554 & 1596 \\
\hline 6 & & 1099 & 310 & 768 & 845 & 1070 & 1189 & 890 & 886 & 1056 & 1290 & 1517 & 1382 & 1184 & 1284 & 1362 & 1121 & 1446 & 1337 & 1391 \\
\hline 7 & & 803 & & & 870 & 1078 & & & 700 & 964 & & 1518 & 1086 & 1081 & 1181 & 1200 & 959 & 1343 & 1175 & 1217 \\
\hline 8 & & 922 & & & 736 & 961 & 1012 & 755 & 708 & 889 & 1181 & 1408 & 1205 & 1007 & 1106 & 1184 & 943 & 1268 & 1159 & 1213 \\
\hline 9 & & 1026 & & & & & 1116 & & & & 760 & 986 & 1139 & 37 & 774 & 1112 & 68 & 970 & 055 & 1147 \\
\hline 10 & 487 & 504 & 390 & 295 & 599 & 641 & 594 & 374 & 343 & 527 & 854 & 1081 & 787 & 644 & 744 & 767 & 526 & 906 & 742 & 796 \\
\hline 11 & & & 162 & & S & 798 & & & 521 & 702 & 1018 & 1244 & 1020 & 820 & 919 & 1000 & 758 & 1081 & 974 & 1028 \\
\hline 12 & 180 & 941 & 674 & 224 & 134 & 358 & 1031 & 872 & 342 & 248 & 571 & 798 & 908 & 557 & 497 & 882 & 637 & 692 & 778 & 917 \\
\hline 13 & 571 & 438 & 844 & 278 & 532 & 446 & 528 & 547 & 163 & 332 & 614 & 769 & 553 & 301 & 401 & 533 & 292 & 563 & 508 & 562 \\
\hline 14 & 728 & 281 & 688 & 436 & 689 & 604 & 371 & 390 & 320 & 490 & 772 & 926 & 490 & 458 & 558 & 469 & 228 & 720 & 444 & 498 \\
\hline 15 & 491 & 817 & 984 & 419 & 326 & 179 & 907 & 944 & 304 & 120 & 208 & 434 & 724 & 262 & 162 & 682 & 452 & 358 & 443 & 732 \\
\hline
\end{tabular}

Table A5: Transportation amounts based on Model-IV.

\begin{tabular}{ccccccccc}
\hline \multirow{2}{*}{ From $j$} & To $i$ & \multicolumn{5}{c}{ Amount of equipment type $m$ to be distributed } \\
\cline { 3 - 7 } & & 1 & 2 & 3 & 4 & 5 & 7 \\
\hline 1 & 1 & 24 & 275 & 400 & 670 & 1400 & 1185 \\
1 & 2 & 150 & 281 & 423 & 674 & 1405 & 1091 \\
1 & 3 & 321 & 340 & 342 & 560 & 1360 & 1299 \\
\hline
\end{tabular}


Table A5'in devamı.

\begin{tabular}{|c|c|c|c|c|c|c|c|c|}
\hline \multirow{2}{*}{ From $j$} & \multirow{2}{*}{ To $i$} & \multicolumn{7}{|c|}{ Amount of equipment type $m$ to be distributed } \\
\hline & & 1 & 2 & 3 & 4 & 5 & 6 & 7 \\
\hline 2 & 9 & 0 & 319 & 640 & 670 & 1940 & 830 & 400 \\
\hline 2 & 13 & 0 & 380 & 421 & 691 & 1951 & 1473 & 870 \\
\hline 2 & 14 & 121 & 324 & 443 & 512 & 1265 & 918 & 832 \\
\hline 3 & 4 & 270 & 468 & 470 & 830 & 1650 & 1180 & 350 \\
\hline 3 & 5 & 190 & 680 & 680 & 560 & 1230 & 1730 & 540 \\
\hline 3 & 6 & 460 & 320 & 870 & 1390 & 1900 & 1670 & 320 \\
\hline 3 & 7 & 193 & 450 & 570 & 690 & 1175 & 1325 & 750 \\
\hline 3 & 10 & 265 & 341 & 390 & 1100 & 1340 & 1670 & 420 \\
\hline 3 & 13 & 56 & 7 & 0 & 0 & 0 & 0 & 0 \\
\hline 4 & 1 & 146 & 0 & 0 & 0 & 0 & 0 & 0 \\
\hline 4 & 8 & 300 & 175 & 480 & 390 & 980 & 1490 & 490 \\
\hline 4 & 9 & 90 & 6 & 0 & 0 & 0 & 0 & 0 \\
\hline 4 & 16 & 71 & 193 & 391 & 943 & 1785 & 1700 & 320 \\
\hline 6 & 7 & 87 & 0 & 0 & 0 & 0 & 0 & 0 \\
\hline 6 & 17 & 112 & 235 & 421 & 751 & 1341 & 1730 & 643 \\
\hline 7 & 12 & 323 & 658 & 275 & 874 & 1390 & 1420 & 630 \\
\hline 7 & 15 & 183 & 88 & 0 & 0 & 0 & 0 & 0 \\
\hline 7 & 20 & 20 & 220 & 224 & 491 & 1863 & 1230 & 1100 \\
\hline 7 & 23 & 3 & 0 & 0 & 0 & 0 & 0 & 0 \\
\hline 8 & 11 & 4 & 0 & 0 & 0 & 0 & 0 & 0 \\
\hline 8 & 23 & 20 & 230 & 211 & 721 & 1308 & 1127 & 879 \\
\hline 9 & 11 & 171 & 235 & 438 & 671 & 985 & 1461 & 934 \\
\hline 9 & 18 & 183 & 342 & 453 & 647 & 1180 & 1649 & 521 \\
\hline 9 & 21 & 70 & 549 & 379 & 672 & 1620 & 1195 & 645 \\
\hline 10 & 15 & 0 & 231 & 479 & 504 & 1318 & 1104 & 648 \\
\hline 10 & 28 & 14 & 95 & 129 & 498 & 2370 & 2190 & 1420 \\
\hline 12 & 21 & 73 & 0 & 0 & 0 & 0 & 0 & 0 \\
\hline 12 & 24 & 0 & 186 & 321 & 764 & 2200 & 1765 & 598 \\
\hline 12 & 25 & 376 & 190 & 210 & 632 & 930 & 1272 & 983 \\
\hline 13 & 24 & 217 & 0 & 0 & 0 & 0 & 0 & 0 \\
\hline 13 & 29 & 99 & 187 & 284 & 342 & 1700 & 1453 & 947 \\
\hline 13 & 34 & 91 & 0 & 0 & 0 & 0 & 0 & 0 \\
\hline 14 & 19 & 61 & 435 & 278 & 447 & 1794 & 860 & 947 \\
\hline 14 & 22 & 102 & 211 & 620 & 387 & 1007 & 998 & 672 \\
\hline 14 & 27 & 173 & 98 & 172 & 731 & 2100 & 1980 & 1002 \\
\hline 14 & 33 & 152 & 231 & 372 & 673 & 1866 & 1160 & 1008 \\
\hline 14 & 36 & 201 & 123 & 324 & 303 & 1452 & 1098 & 999 \\
\hline 14 & 37 & 79 & 165 & 342 & 290 & 890 & 1720 & 1023 \\
\hline 14 & 39 & 26 & 0 & 0 & 0 & 0 & 0 & 0 \\
\hline 14 & 40 & 154 & 283 & 476 & 623 & 1439 & 1632 & 1321 \\
\hline 15 & 26 & 78 & 159 & 301 & 464 & 1674 & 791 & 983 \\
\hline 15 & 30 & 30 & 97 & 231 & 489 & 1290 & 1673 & 1003 \\
\hline 15 & 31 & 91 & 283 & 210 & 539 & 1005 & 1293 & 932 \\
\hline 15 & 32 & 210 & 152 & 320 & 431 & 1302 & 1329 & 789 \\
\hline 15 & 34 & 43 & 241 & 290 & 378 & 2172 & 1175 & 875 \\
\hline 15 & 35 & 35 & 197 & 198 & 231 & 1321 & 1123 & 786 \\
\hline 15 & 38 & 167 & 191 & 367 & 402 & 1126 & 1238 & 793 \\
\hline 15 & 39 & 70 & 218 & 287 & 523 & 1523 & 1342 & 1039 \\
\hline
\end{tabular}

